\title{
GARRLiC and LIRIC: strengths and limitations for the characterization of dust and marine particles along with their mixtures
}

\author{
Alexandra Tsekeri ${ }^{1}$, Anton Lopatin ${ }^{2}$, Vassilis Amiridis ${ }^{1}$, Eleni Marinou ${ }^{1,3}$, Julia Igloffstein $^{4}$, Nikolaos Siomos $^{3}$, \\ Stavros Solomos ${ }^{1}$, Panagiotis Kokkalis ${ }^{1,5}$, Ronny Engelmann ${ }^{4}$, Holger Baars ${ }^{4}$, Myrto Gratsea ${ }^{6}$, Panagiotis I. Raptis ${ }^{6,7}$, \\ Ioannis Binietoglou ${ }^{8}$, Nikolaos Mihalopoulos ${ }^{6,9}$, Nikolaos Kalivitis ${ }^{1,9}$, Giorgos Kouvarakis ${ }^{9}$, Nikolaos Bartsotas ${ }^{10}$, \\ George Kallos $^{10}$, Sara Basart ${ }^{11}$, Dirk Schuettemeyer ${ }^{12}$, Ulla Wandinger ${ }^{4}$, Albert Ansmann ${ }^{4}$, Anatoli P. Chaikovsky ${ }^{13}$, \\ and Oleg Dubovik ${ }^{2}$ \\ ${ }^{1}$ Institute for Astronomy, Astrophysics, Space Applications and Remote Sensing, \\ National Observatory of Athens, Athens, Greece \\ ${ }^{2}$ Laboratoire d' Optique Atmosphérique, Universite de Lille, Lille, France \\ ${ }^{3}$ Laboratory of atmospheric physics, Physics Department, Aristotle University of \\ Thessaloniki, Thessaloniki, Greece \\ ${ }^{4}$ Leibniz Institute for Tropospheric Research, Leipzig, Germany \\ ${ }^{5}$ Physics Department, Faculty of Science, Kuwait University, Kuwait \\ ${ }^{6}$ IERSD, National Observatory of Athens, Athens, Greece \\ ${ }^{7}$ Physikalisch-Meteorologisches Observatorium Davos/World Radiation Center (PMOD/WRC), \\ Davos Dorf, Switzerland \\ ${ }^{8}$ National Institute of R\&D for Optoelectronics, Magurele, Ilfov, Romania \\ ${ }^{9}$ Environmental Chemical Processes Laboratory, University of Crete, Heraklion, Greece \\ ${ }^{10}$ University of Athens, School of Physics, Athens, Greece \\ ${ }^{11}$ Barcelona Supercomputing Center, Barcelona, Spain \\ ${ }^{12}$ European Space Agency, ESTEC, Noordwijk, the Netherlands \\ ${ }^{13}$ Institute of Physics, NAS of Belarus, Minsk, Belarus
}

Correspondence: Alexandra Tsekeri (atsekeri@noa.gr)

Received: 26 June 2017 - Discussion started: 17 July 2017

Revised: 14 September 2017 - Accepted: 4 October 2017 - Published: 20 December 2017

\begin{abstract}
The Generalized Aerosol Retrieval from Radiometer and Lidar Combined data algorithm (GARRLiC) and the LIdar-Radiometer Inversion Code (LIRIC) provide the opportunity to study the aerosol vertical distribution by combining ground-based lidar and sun-photometric measurements. Here, we utilize the capabilities of both algorithms for the characterization of Saharan dust and marine particles, along with their mixtures, in the south-eastern Mediterranean during the CHARacterization of Aerosol mixtures of Dust and Marine origin Experiment (CHARADMExp). Three case studies are presented, focusing on dust-dominated, marinedominated and dust-marine mixing conditions. GARRLiC and LIRIC achieve a satisfactory characterization for the
\end{abstract}

dust-dominated case in terms of particle microphysical properties and concentration profiles. The marine-dominated and the mixture cases are more challenging for both algorithms, although GARRLiC manages to provide more detailed microphysical retrievals compared to AERONET, while LIRIC effectively discriminates dust and marine particles in its concentration profile retrievals. The results are also compared with modelled dust and marine concentration profiles and surface in situ measurements. 


\section{Introduction}

The importance of studying the vertical distribution of aerosol plumes is prominent in regional and climate studies, since it can effectively change the radiative properties of the atmosphere and the presence of clouds (e.g. Pérez et al., 2006; Solomon et al., 2007). Ground-based monitoring of the aerosol vertical structure is effectively performed with the synergy of passive and active remote sensing instruments, in particular with multi-wavelength sun-photometers and lidars. The sun-photometer provides the columnar properties of the particles (e.g. Dubovik and King, 2000; Dubovik et al., 2006), whereas the lidar is capable of providing vertical profiles of the backscatter and extinction coefficients, along with vertical profiles of the particle microphysical properties, mainly for the fine mode (e.g. Müller et al., 2016). The combination of active and passive remote sensing has been tried so far mostly by using the sun-photometer-measured aerosol optical depth (AOD) as ancillary information for the lidar retrieval (e.g. Fernald et al., 1972; Ansmann et al., 2011, 2012). The GARRLiC (Generalized Aerosol Retrieval from Radiometer and Lidar Combined data algorithm; Lopatin et al., 2013) and LIRIC (LIdar-Radiometer Inversion Code; Chaikovsky et al., 2016) algorithms go a step further and use deeper synergies: the LIRIC approach derives the particle concentration profiles from the lidar measurements, using the columnar microphysical properties derived separately from the sun-photometer; GARRLiC advances the method even more, combining for the first time both sun-photometer and lidar measurements for the retrieval of the particle microphysical properties. As discussed in detail in Lopatin et al. (2013), combining the sun-photometer intensity measurements with the backscatter lidar information seems to result in better sensitivity to the particle shape and the ability to retrieve the refractive indices of fine and coarse particles separately as well as to extract the vertical distribution of the fineand coarse-particle concentrations. Moreover, it can potentially provide higher accuracy for cases of low aerosol loadings, compared with the intensity-only retrieval.

GARRLiC and LIRIC have been developed in the framework of the Aerosols, Clouds and Trace gases Research Infrastructure (ACTRIS, http://www.actris.eu/), utilizing the capabilities of the combined European stations of the AErosol RObotic NETwork (AERONET, Holben et al., 1998) and the European Aerosol Research Lidar Network (EARLINET, Pappalardo et al., 2014). Both algorithms have been tested for a variety of aerosol types and their mixtures. For example, LIRIC has been tested for dust and volcanic aerosols (Wagner et al., 2013), dust-pollution mixture (Tsekeri et al., 2013), dust, pollution and a mixture of dust, smoke and pollution (Granados-Muñoz et al., 2014, 2016a; Papayannis et al., 2014) and smoke-pollution mixture (Kokkalis et al., 2017). LIRIC has also been used to study dust transport events and dust modelling performance over Europe (Binietoglou et al., 2015; Granados-Muñoz et al., 2016b), as well as to evaluate air quality models (Siomos et al., 2017). GARRLiC has been tested for dust and smoke (Lopatin et al., 2013) and dust aerosols (Bovchaliuk et al., 2016; Benavent-Oltra et al., 2017).

GARRLiC and LIRIC input and output data are shown in Fig. 1, while short descriptions are given herein: the LIRIC algorithm uses the particle microphysical properties provided in the AERONET product as a priori information in the inversion of the lidar measurements for retrieving the aerosol volume concentration profiles. Using lidar measurements of elastic backscatter at three wavelengths of 355,532 and $1064 \mathrm{~nm}$, LIRIC retrieves the volume concentration profiles of fine and coarse particles. Moreover, the cross-polarized lidar signal at $532 \mathrm{~nm}$ allows the decoupling of the coarse mode into its spherical and non-spherical components. The error estimation of the retrieved profiles is provided as well. Both LIRIC and GARRLiC suppress unrealistic oscillations in the retrieved quantities (e.g. aerosol concentration) but otherwise do not constrain their absolute values. In this way the algorithms exclude solutions that are mathematically possible but contain unrealistic oscillations in the retrieved properties (see also Dubovik, 2004; Dubovik and King, 2000). The GARRLiC algorithm synergistically combines the sunphotometer sun and sky measurements at four wavelengths (at $440,670,870$ and $1020 \mathrm{~nm}$ ) and up to 35 scattering angles, with the vertically resolved lidar measurements of the elastic backscatter at three wavelengths (at 355, 532 and $1064 \mathrm{~nm}$ ). The algorithm does not use the AERONET products, but it instead calculates the size distribution, spherical particle fraction and spectral complex refractive index, separately for fine and coarse particles. In the case of a dominant mode (e.g. for pure dust cases), the algorithm is set to retrieve the aerosol characteristics for one mode only. Although in GARRLiC the microphysical properties are considered to be constant along the column for each mode, the total values change along the column in the case of two modes with different properties. The algorithm also calculates the volume concentration profiles of fine and coarse particles. The concentrations are considered constant below the lowest height of the lidar signals, which may introduce errors in the retrieved profiles (e.g. Tsekeri et al., 2013). The retrieval uncertainties of the microphysical parameters are provided as well, following the approach described by Dubovik et al. (2000) and the profile retrieval uncertainties are currently under development. GARRLiC and its updates are available for download at http://www.grasp-open.com/doc/ch04.php\# grasp-manager, as part of the GRASP code (Dubovik et al., 2014).

In the case of multimode aerosol mixtures and/or changes in microphysical properties with height due to particle hygroscopic growth, an inherent deficiency of both algorithms is the number of aerosol modes retrieved, with LIRIC retrieving three modes (fine particles, coarse spherical and coarse non-spherical particles) and GARRLiC two modes (fine and coarse particles). We need to highlight here that LIRIC re- 


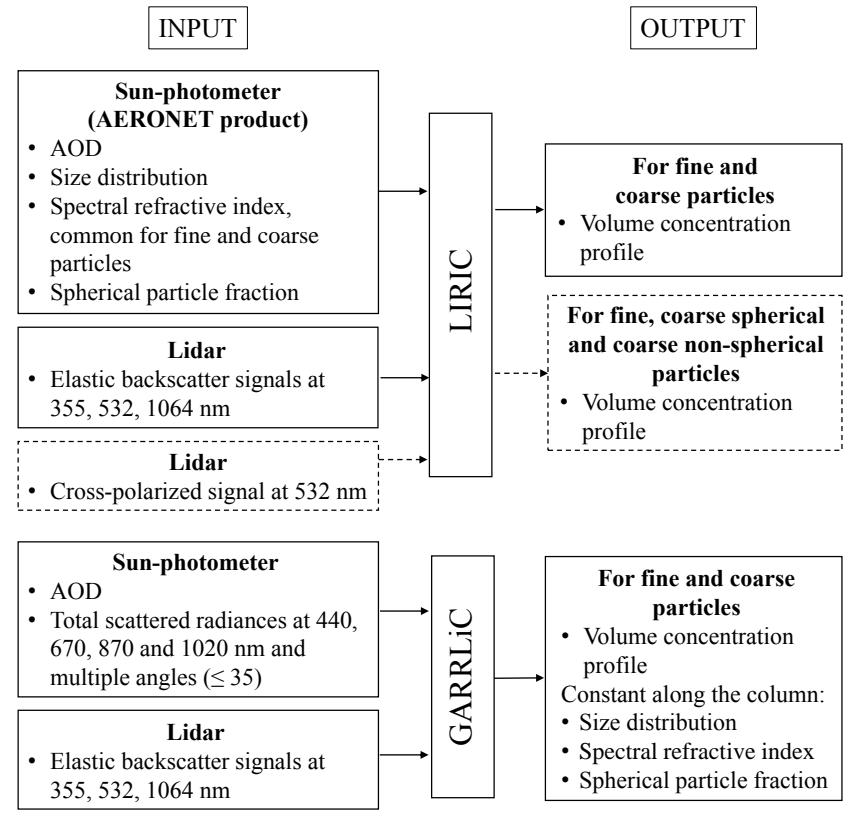

Figure 1. GARRLiC and LIRIC algorithm input and output parameters. For LIRIC, the output when using the cross-polarized signal at $532 \mathrm{~nm}$ is shown in the dashed box.

trieves three modes only for the volume concentration profiles, whereas otherwise it uses the AERONET products by providing, for example, a common spectral refractive index for all modes (Fig. 1). Both algorithms work well for individual aerosol components or mixtures of (mainly) fine (e.g. pollution) and (mainly) coarse (e.g. dust) particles, but they should not be able to fully characterize the mixture components in the case of more than one fine or coarse mode in the mixture, such as in smoke-pollution or dust-marine mixture cases. For the latter, LIRIC should provide an effective characterization for the volume concentration profiles, since it derives the coarse spherical (hydrated marine) particles and the non-spherical (dust) particles, but the characterization is not expected to be satisfactory for the particle microphysical properties.

In our study, we apply GARRLiC and LIRIC to cases of dust, marine and a dust-marine mixture during the CHARADMExp (CHARacterization of Aerosol mixtures of Dust and Marine origin Experiment) campaign in the southeastern Mediterranean. This is the first time a detailed characterization of marine and marine mixtures with dust along the atmospheric column is performed for the area. So far, various studies have tried to characterize the aerosol radiative properties in the Mediterranean with satellite or ground-based AOD measurements (e.g. di Sarra et al., 2008; Kazadzis et al., 2009; Papadimas et al., 2012). Unfortunately, they fail to overcome their limitations, such as the non-realistic assumptions about the aerosol absorption properties and the lack of information on the real vertical aerosol structure (Mishra et al., 2014). The kind of characterization presented here is important for application in future satellite missions, not only for the Mediterranean but for large parts of the globe where dust and marine particles are present, such as in the Atlantic Ocean (e.g. Prospero, 1996).

The CHARADMExp campaign and the three cases (i.e. mainly dust, marine-pollution mixture and dust-marinepollution mixture) are presented in Sect. 2. The methodology followed in our work is presented in Sect. 3, the GARRLiC and LIRIC results are shown in Sect. 4 and finally our conclusions are given in Sect. 5.

\section{Overview of the CHARADMExp campaign and data sets}

CHARADMExp was an experimental campaign of ESA, implemented by the National Observatory of Athens (NOA), aimed to characterize dust and marine particles along with their mixtures (http://charadmexp.gr). The campaign took place at the ACTRIS Finokalia Station $\left(35.338^{\circ} \mathrm{N}\right.$, $25.670^{\circ} \mathrm{E}$ ) on the northern coast of Crete, Greece (Fig. 2), from 20 June to 20 July 2014 . The station is situated at the top of a hilly elevation ( $252 \mathrm{~m}$ above sea level) and it is a background site with no human activities occurring at distances less than $15 \mathrm{~km}$ away, making the station ideal for monitoring natural aerosols mainly of desert and marine origin. The area is characterized by the existence of two equally long, well-distinguished seasons: the dry season from April to September and the wet season from October to April. The dry season is characterized mainly by winds from N-NW direction (central and eastern Europe and Balkans) carrying smoke and long-range-transported anthropogenic pollution to the area (Sciare et al., 2008; Vrekoussis et al., 2005) and the wet season has less pronounced N-NW winds and significant transport from the Sahara desert (S-SW winds; occurrence up to $20 \%$ ). Dust transport, while less frequent during the dry period, is still observed (e.g. Marinou et al., 2017) and is characterized by a transportation pattern through the free troposphere and weaker vertical mixing of the dust layers (e.g. Kalivitis et al., 2007).

\subsection{Instruments and methods}

\subsubsection{Lidar}

The Polly ${ }^{\mathrm{XT}}$ OCEANET lidar (Engelmann et al., 2016) operated on a 24/7 basis during CHARADMExp, measuring aerosol loads in the boundary layer and the free troposphere. The system was provided by the Leibniz Institute for Tropospheric Research (TROPOS - http://www.tropos.de). It employs three backscatter channels (at 355, 532 and $1064 \mathrm{~nm}$ ), two Raman extinction channels (at 387 and at $607 \mathrm{~nm}$ ), two depolarization channels (at 355 and $532 \mathrm{~nm}$ ) and one watervapour channel (at $407 \mathrm{~nm}$ ). The lidar is housed in a container and can be operated under various climatic conditions. The 
(a)

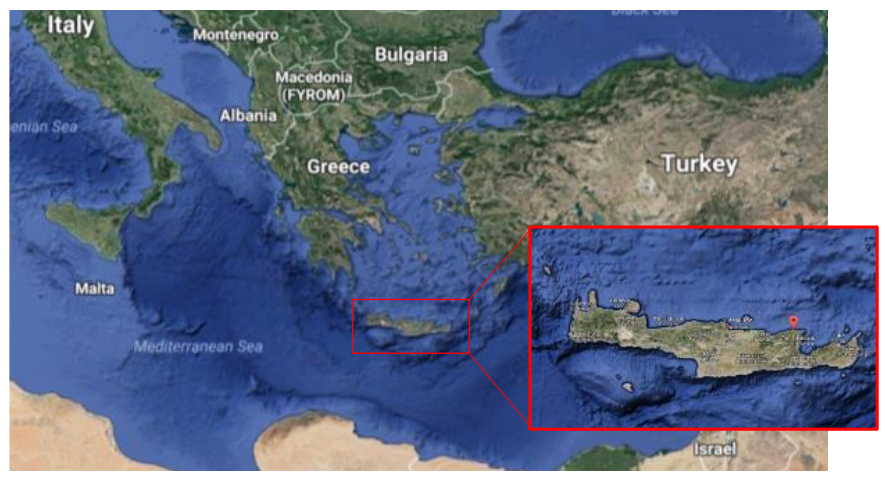

(b)

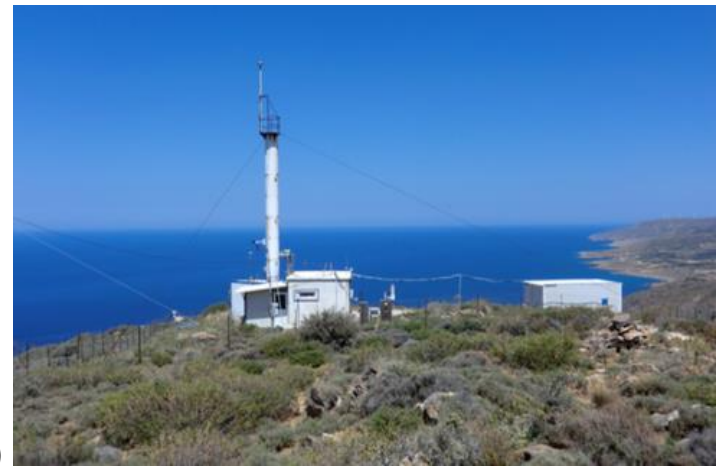

Figure 2. (a) Location of Finokalia Station (red dot) in Crete island, Greece. (b) Sea view from the station.

full description of the original lidar system can be found in Althausen et al. (2009) and in Engelmann et al. (2016). More about the network of Polly systems (i.e. Polly ${ }^{\mathrm{NET}}$ ) can be found in Baars et al. (2016).

The information close to the surface is very important for our study, especially for the marine-particle characterization, since the marine particles reside mostly below $1 \mathrm{~km}$ (e.g. Ho et al., 2015). Unfortunately, this is also the lidar "overlap region", with large uncertainty for the lidar backscattered signal due to its partial collection from the telescope (e.g. Wandinger and Ansmann, 2002). The Polly ${ }^{\mathrm{XT}}$ OCEANET far-field (FF) signal full overlap is at $\sim 800 \mathrm{~m}$ (Engelmann et al., 2016) and it operates two near-field (NF) channels utilizing a separate $50 \mathrm{~mm}$ refractor telescope at a distance of $120 \mathrm{~mm}$ from the axis of the laser beam, providing a full overlap at $150 \mathrm{~m}$ above the surface at 532 and $607 \mathrm{~nm}$. The NF measurements are not used in GARRLiC and LIRIC, since both algorithms require the complete set of wavelengths provided by the lidar during CHARADMExp only for the FF measurements. Nevertheless, we use the NF measurements to perform overlap correction in the FF signals, as described in Engelmann et al. (2016) and this allowed us to use the FF-corrected lidar signals from $\sim 550 \mathrm{~m}$ instead of $800 \mathrm{~m}$. In future efforts we plan to utilize the additional information provided by our new Polly ${ }^{\mathrm{XT}}$ lidar system currently installed at Finokalia Station to measure NF signals at both 355 and $532 \mathrm{~nm}$ by performing the signal gluing technique for NF and FF signals at 355 and $532 \mathrm{~nm}$ and the overlap correction for the FF signal at $1064 \mathrm{~nm}$.

\subsubsection{Sun-photometer}

The CIMEL CE318 sun-photometer is the instrument used in the AERONET sun-photometer network, with more than 250 units worldwide. The technical specifications of the instrument are given in detail by Holben et al. (1998). Taking into account all the information about the instrument and calibration precision (Holben et al., 1998) the accuracy of the AOD measurements is estimated to be of the order of \pm 0.02 in the UV and \pm 0.01 in the visible range regarding the level 2 (cloud-screened and quality-assured) data. In the current analysis we utilized the level 1.5 products (i.e. automatically cloud cleared but may not have final calibration applied) for the LIRIC retrieval, since the level 2 data were not available in the time ranges selected for the retrievals. For the GARRLiC retrieval we used the sun and sky multiangle measurements at four wavelengths $(440,670,870$ and $1020 \mathrm{~nm}$ ) (Dubovik and King, 2000).

\subsubsection{Surface in situ}

The GARRLiC-retrieved size distribution is evaluated against the surface measurements of the Scanning Mobility Particle Spectrometer (SMPS). SMPS provides the fineparticle number size distribution at $\sim 9-848 \mathrm{~nm}$ (nominal) radius. Unfortunately, there were no size distribution measurements for the coarse particles at Finokalia Station during CHARADMExp. Note that for a direct comparison of the SMPS number size distribution (in $\mathrm{cm}^{-3}$ ) with the GAR$\mathrm{RLiC}$ volume size distribution retrievals (in $\mu \mathrm{m}^{3} \mu \mathrm{m}^{-2}$ ), we first have to calculate the SMPS volume size distribution (in $\mu \mathrm{m}^{3} \mathrm{~cm}^{-3}$ ) and then multiply it with the height extent of fine particles in the column, derived by the collocated lidar measurements.

Moreover, we evaluate the particle concentration derived from GARRLiC and LIRIC at the surface level with the surface in situ measurements of the particular matter for particles with diameters less than $10 \mu \mathrm{m}\left(\mathrm{PM}_{10}\right)$. The $\mathrm{PM}_{10}$ is continuously measured at Finokalia Station with an Eberline FH 62 I-R (Eberline Instruments $\mathrm{GmbH}$ ) particulate monitor (Gerasopoulos et al., 2006). GARRLiC and LIRIC retrieve the particle concentration for a wider size range (up to $15 \mu \mathrm{m}$ in radius, or $30 \mu \mathrm{m}$ in diameter); thus their $\mathrm{PM}_{10}$ values are calculated using the respective volume percentages for particles with radii less than $5 \mu \mathrm{m}$.

In order to compare the in situ measured size distribution and mass concentration with the GARRLiC and LIRIC ambient retrievals, we need to take into account the particle drying applied to surface measurements. The in situ instruments dry the sampled air by adiabatic compression during the sam- 
pling through their inlets and by the radiant heat from the lights inside the instruments. The size and mass of the ambient particles thus change, especially in the case of hygroscopic particles in humid conditions (e.g. Snider and Petters, 2008). For the size distribution we evaluate this effect qualitatively (see Sect. 4.2 and 4.3). For the $\mathrm{PM}_{10}$ comparison we calculate the "dry" GARRLiC and LIRIC PM 10 using the particle hygroscopic growth (i.e. the ratio of the ambient to dry particle size, $f_{g}$ ) as shown in Eq. (1):

$\mathrm{PM}_{10 \mathrm{~d}}=f_{g}^{-3} \mathrm{PM}_{10 \mathrm{a}}$

where $\mathrm{d}$ and a denote the dry and ambient particles.

We derive $f_{g}$ for different relative humidity (RH) values using the hygroscopicity parameter $\kappa$ (Petters and Kreidenweis, 2007) as shown in Eq. (2):

$f_{g}=\left(1+\kappa \frac{\mathrm{RH}}{100-\mathrm{RH}}\right)^{\frac{1}{3}}$

For the cases analysed herein, we consider a $\kappa$ value of 0.4 to be characteristic for particles in the south-eastern Aegean Sea (Bezantakos et al., 2013). A more detailed comparison of dry in situ measurements with ambient remote sensing retrievals is outside the scope of this analysis, but it is very important when combining these different techniques (e.g. Tsekeri et al., 2017).

\subsection{Models}

\subsubsection{Source-receptor analysis}

The origin of the examined aerosol layers at Finokalia Station is investigated with the use of source-receptor computations derived with dispersion modelling tools. The corresponding emission sensitivity (i.e. the residence time of the tracer particles inside the lowest tropospheric layers) is calculated from backward Lagrangian simulations with the atmospheric dispersion model FLEXPART-WRF (Brioude et al., 2013). The dispersion model is coupled offline with the WRF_ARW atmospheric model (Skamarock et al., 2008). The spatial resolution of WRF is $12 \times 12 \mathrm{~km}$ and we use its hourly outputs to drive the FLEXPART runs. This configuration allows for the simulation of meso- $\gamma$-scale circulations, which play an important role in the planetary boundary layer properties and the regional- and local-scale transport of the particles. The backward FLEXPART runs are performed for 5-day periods and we assume a release of 40000 tracer particles from each layer arriving over Finokalia Station. The modelled retroplume maps show the spatial distribution of the tracer particle residence time below $1 \mathrm{~km}$. Thus, the areas showing longer residence times in these maps indicate the source areas/origin of the particles arriving at the specific heights above Finokalia Station.

\subsubsection{Desert dust model}

Desert dust emissions and transport are described with the BSC-DREAM8b model (Nickovic et al., 2001; Pérez et al., 2006; Basart et al., 2012a). The BSC-DREAM8b model is embedded into the Eta/NCEP atmospheric model and solves the mass balance equation for dust, taking into account the different processes of the dust cycle (i.e. dust emission, transport and deposition). The updated version of the model includes a source function based on the $1 \mathrm{~km}$ USGS land use data, eight particle size bins $(0.1-10 \mu \mathrm{m}$ radius range) and dust-radiative feedbacks. The present analysis utilize the BSC-DREAM8b dust simulations for the period from 20 June to 20 July 2014 with hourly output. The initial state of dust concentration in the model is defined by the $24 \mathrm{~h}$ forecast from the previous day's model run. The NCEP Final Operational Global Analysis data (at $1^{\circ} \times 1^{\circ}$ horizontal resolution) at 00:00 UTC are used as initial conditions and boundary conditions at intervals of $6 \mathrm{~h}$. Moreover, the model configuration includes 24 Eta vertical layers extending up to approximately $15 \mathrm{~km}$ in the vertical. The resolution is set to $0.33^{\circ}$ in the horizontal.

\subsubsection{Sea salt model}

Sea salt emissions and transport are described with the atmospheric model RAMS-ICLAMS (Solomos et al., 2011). The model is an enhanced version of RAMS (Pielke et al., 1992; Cotton et al., 2003) and it includes a full description of the sea salt life cycle in the atmosphere. The parameterization of sea salt emission is based on the white-cap formation for the entrainment of sea salt spray in the atmosphere (Monahan et al., 1986), also taking into account the effects of RH on the size distribution of the particles (Zhang et al., 2005). Sea salt flux close to the coastline is also calculated in the model following the parameterizations of Leeuw et al. (2000) and Gong et al. (2002). The dry and wet removal processes are treated with the corresponding schemes described in Seinfeld and Pandis (1998). The simulated sea salt mass is represented with a bimodal log-normal distribution. The first (accumulated) mode has a mean diameter of $0.36 \mu \mathrm{m}$ and a geometric dispersion of 1.80. The second (coarse) mode has a mean diameter of $2.85 \mu \mathrm{m}$ and the geometric dispersion is 1.90 .

\section{Results}

In order to demonstrate the GARRLiC and LIRIC capabilities in characterizing events with dust and marine particles, we analyse in detail three cases acquired during CHARADMExp at Finokalia. The first case is a relatively moderate dust episode with a low amount of marine and continental particles, the second is a low-AOD marine and continental plume and the last is a mixture of dust, marine and continental particles. Source-receptor simulations are used to derive the particle origin and characterize the air masses. Then, 

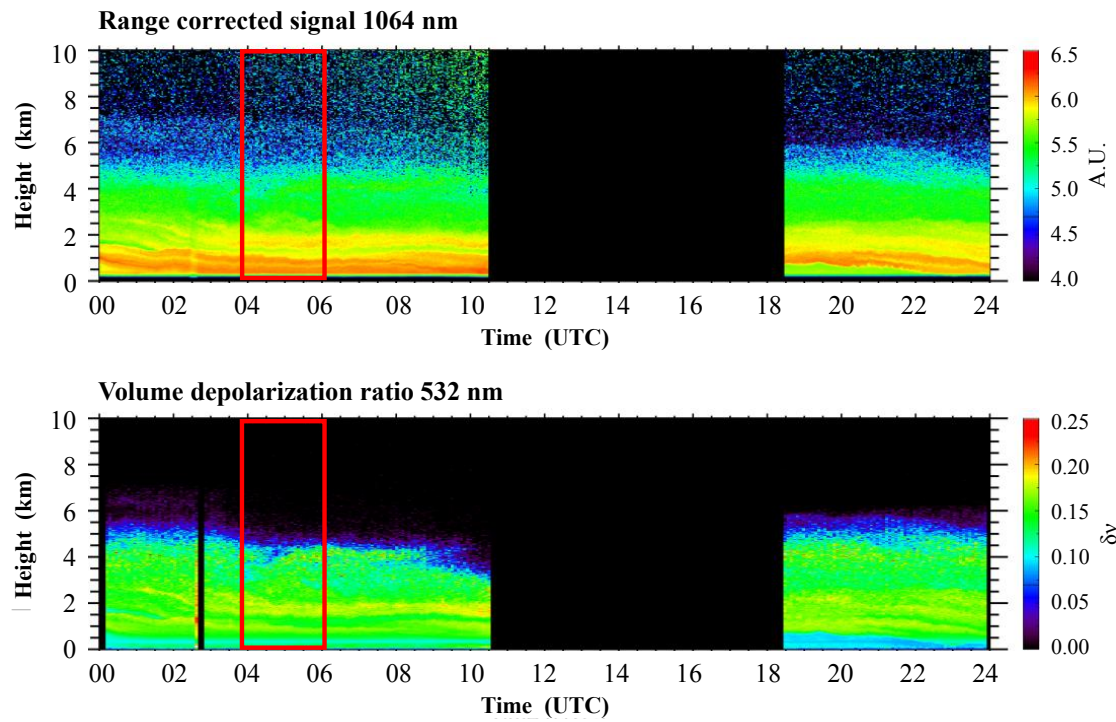

(a)

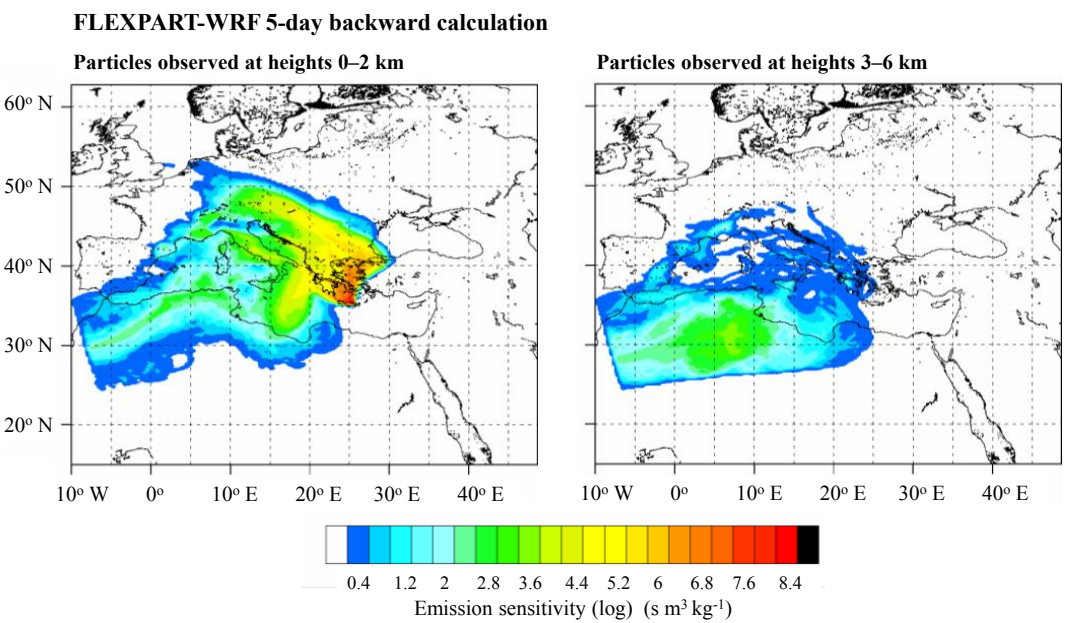

Figure 3. a) Range-corrected backscattered signal at $1064 \mathrm{~nm}$ in arbitrary units (top) and volume depolarization ratio at $532 \mathrm{~nm}$ (bottom) from Polly ${ }^{X T}$ OCEANET lidar at Finokalia, Crete on 26 June 2014. The red rectangle indicates the time range of the measurements used for GARRLiC and LIRIC retrievals (04:00-06:00 UTC). (b) Five-day backward FLEXPART-WRF calculation of emission sensitivity (i.e. residence time in the lowest $1 \mathrm{~km}$ in the atmosphere) in $\log \left(\mathrm{s} \mathrm{m}^{3} \mathrm{~kg}^{-1}\right)$ for the particles arriving at $0-2 \mathrm{~km}$ (left) and 3-6 km (right) at 04:00 UTC.

we compare the optical properties retrieved from GARRLiC, LIRIC and collocated Klett retrievals (Klett, 1985). The GARRLiC and LIRIC/AERONET fine-mode size distributions and $\mathrm{PM}_{10}$ concentrations are compared with surface in situ measurements. Finally, the dust and marine concentration profiles are compared with the corresponding profiles from the BSC-DREAM8b and RAMS-ICLAMS models.

\subsection{Dust-dominated case}

On 26 June the Polly XT measurements of volume depolarization ratio at $532 \mathrm{~nm}$ showed the advection of non-spherical particles (volume depolarization ratio at $532 \mathrm{~nm}$ of $0.15-0.2$ ), at height ranges extending from close to the ground up to 5$6 \mathrm{~km}$ (Fig. 3a) and an AOD at $440 \mathrm{~nm}$ of 0.4 . Model simu- lations also support our observations: dust transport simulations using the BSC-DREAM8b model indicate Saharan dust transport to Finokalia. As shown by the FLEXPART footprints in Fig. 3b, the particles extending from the ground up to $2 \mathrm{~km}$ have possible near-surface sources in the western Sahara region, with potential mixing of marine and continental particles from the western Mediterranean region, the Balkans and Greece, while the particles arriving at 3$6 \mathrm{~km}$ are most likely dust from the Sahara desert between $0-10^{\circ} \mathrm{E}$ and $25-35^{\circ} \mathrm{N}$. The presence of dust particles is indicated by AERONET as well, with an Ångstrom exponent at $440 / 870 \mathrm{~nm}$ of $\sim 0.1$, sphericity parameter $<2.3 \%$ and a coarse-mode-dominated size distribution. These values are 

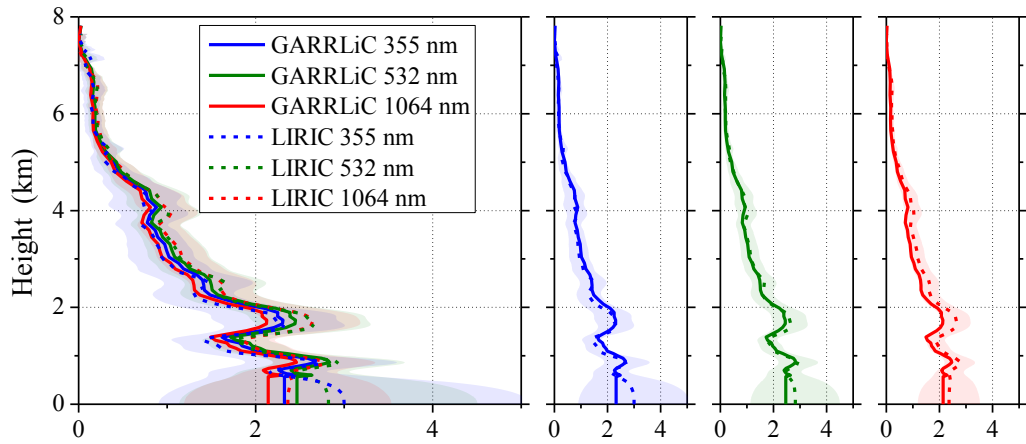

(a)

Backscatter coefficient $\left(\mathrm{Mm}^{-1} \mathrm{sr}^{-1}\right)$
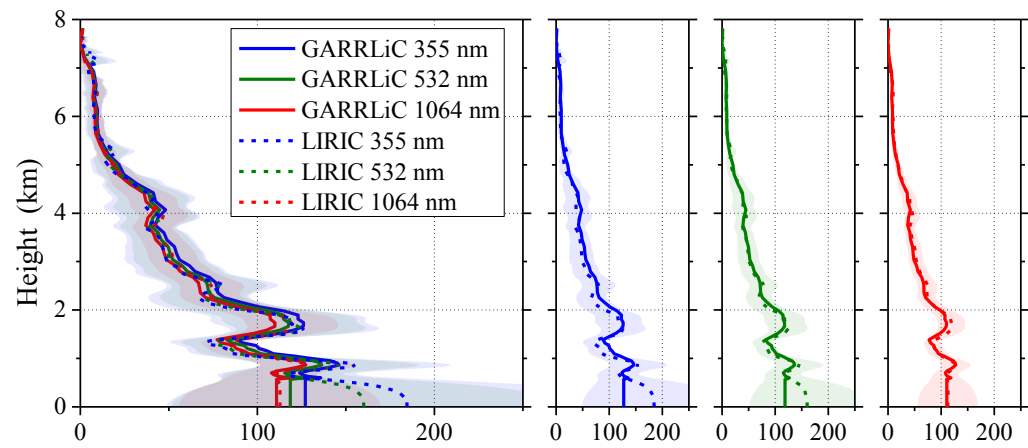

(b)

Extinction coefficient $\left(\mathrm{Mm}^{-1}\right)$
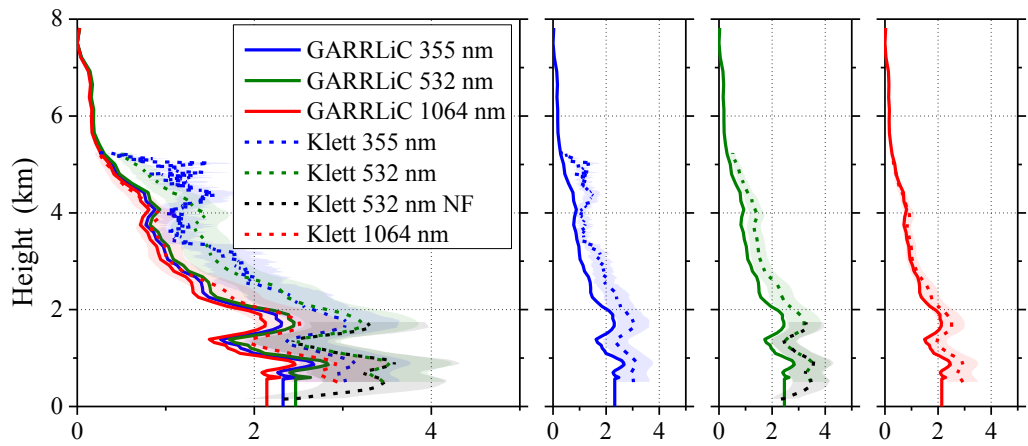

(c)

Backscatter coefficient $\left(\mathrm{Mm}^{-1} \mathrm{sr}^{-1}\right)$
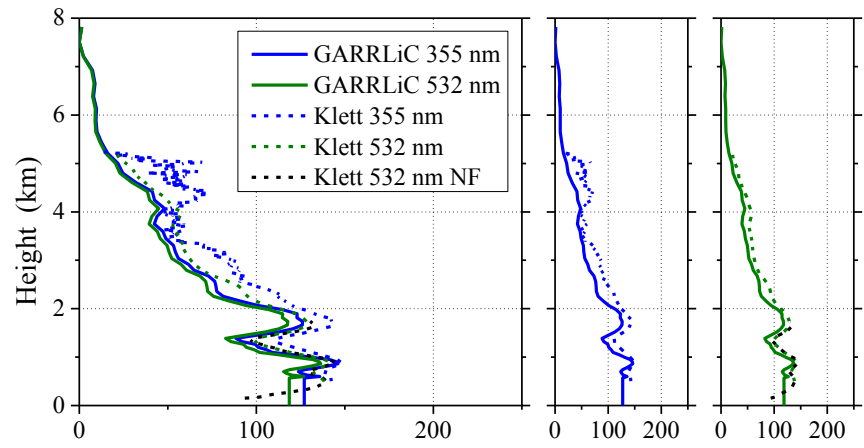

(d)

Extinction coefficient $\left(\mathrm{Mm}^{-1}\right)$

Figure 4. Backscatter and extinction coefficient retrievals at Finokalia, Crete on 26 June 2014, at 04:00-06:00 UTC. (a, b) Backscatter and extinction coefficients from GARRLiC and LIRIC. (c, d) Backscatter and extinction coefficients from GARRLiC and Klett. In each row the first plot contains the results for all wavelengths (i.e. 355, 532 and $1064 \mathrm{~nm}$ ) and the next three plots contain the results for each wavelength separately. 

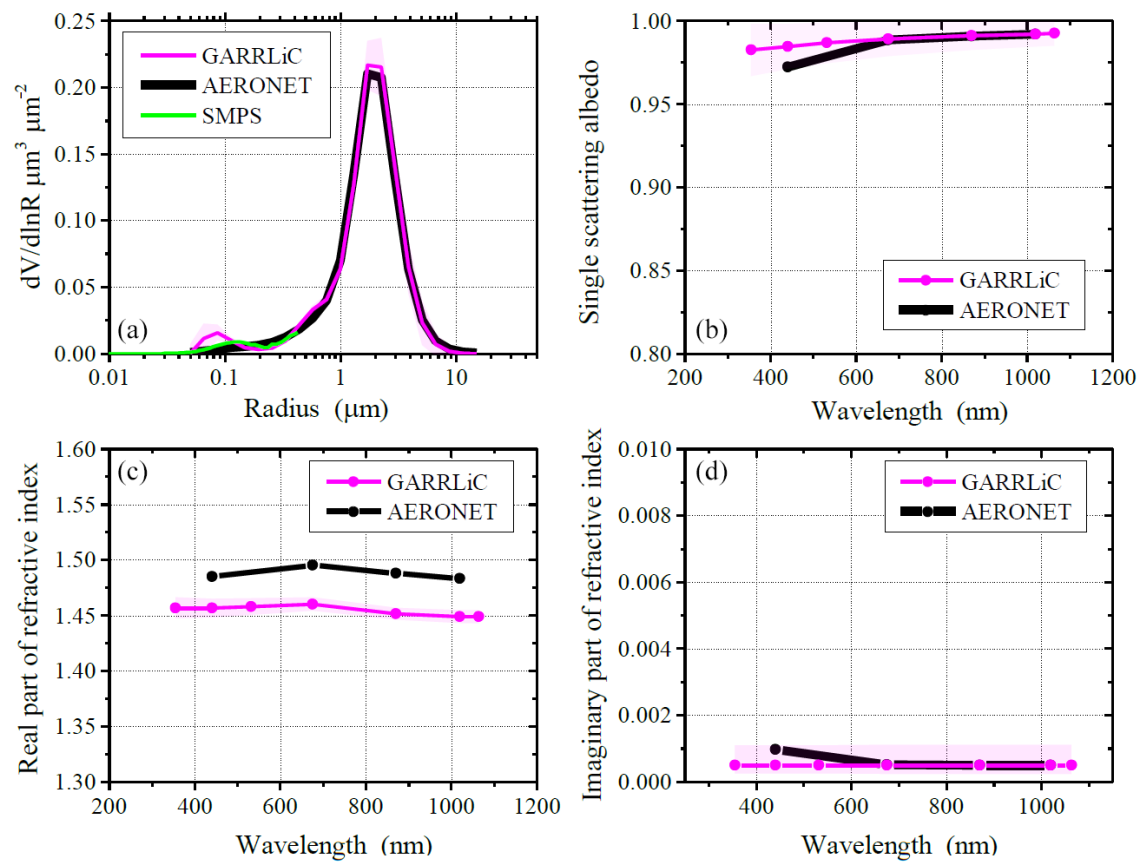

Figure 5. GARRLiC retrievals (pink) of size distribution (a), spectral SSA (b), spectral real and imaginary part of the refractive index (c, d) at Finokalia, Crete on 26 June 2014, at 04:00-06:00 UTC. The black line shows the AERONET retrieval at 04:54 UTC (also used in LIRIC). The green line in the size distribution plot (a) is the mean value of the surface in situ SMPS measurements at 04:00-06:00 UTC.

characteristic for dust particles, as reported in the 8-year global AERONET climatology of Dubovik et al. (2002).

Considering that the atmospheric column is dominated by dust (as shown in the coarse-mode-dominated AERONET size distribution), we performed the one-mode GARRLiC inversion. For both GARRLiC and LIRIC we used the lidar measurements at 04:00-06:00 UTC (red box in Fig. 3a) and the sun-photometer measurements at 04:54 UTC. Our results show that GARRLiC and LIRIC backscatter and extinction coefficient profiles at 355, 532 and $1064 \mathrm{~nm}$ agree quite well, with their differences being 10-20\% with respect to GARRLiC values, well within the LIRIC uncertainties (Fig. 4a and b). Larger differences are seen below $\sim 550 \mathrm{~m}$ in the lidar incomplete-overlap region. Figure 4 also shows the comparison of GARRLiC backscatter and extinction coefficients with the ones produced with the Klett method (Klett, 1985). The Klett profiles are restricted to $5 \mathrm{~km}$, since the low signalto-noise ratio of the daytime lidar measurements introduces large uncertainty to the Klett retrievals above that height. For the Klett retrievals we used an extinction-to-backscatter ratio or lidar ratio (LR) of $40 \mathrm{sr}$ for 532 and $1064 \mathrm{~nm}$ and of $47 \mathrm{sr}$ for $355 \mathrm{~nm}$, which result in extinction coefficient profiles that closely reproduce the sun-photometer-measured AODs at 340,500 and $1020 \mathrm{~nm}$ (i.e. $0.42,0.42$ and 0.38). Due to the assumed lidar ratios a $20 \%$ uncertainty was taken into account in the backscatter retrievals (Fig. 4c). The agreement of GARRLiC and Klett retrievals is considered satisfactory, with differences for the backscatter coefficient within the
Klett retrieval uncertainty, and for the extinction coefficient less than $30 \%$ at heights above $550 \mathrm{~m}$ (Fig. 4d). Figure 4d also shows the NF retrievals at $532 \mathrm{~nm}$, providing information on the particle properties down to $150 \mathrm{~m}$. In particular, we see a decrease in the particle backscatter and extinction coefficients near the surface, which is not retrieved by GARRLiC or LIRIC due to missing NF information as discussed in Sect. 3.1.1.

A special feature seen in GARRLiC, LIRIC and Klett backscatter profiles is the larger backscatter at 532 than $355 \mathrm{~nm}$. This is not usual for dust particles, but it has been reported before: Veselovskii et al. (2016) showed a similar spectral dependence for dust during the SaHAran Dust Over western Africa (SHADOW) campaign, which they attributed to large dust-particle spectral variation of the imaginary part of the refractive index. More specifically, they managed to reproduce this backscatter spectral dependence with imaginary part values of $\sim 0.01$ at $355 \mathrm{~nm}$ and 0.005 at $532 \mathrm{~nm}$. Although these values are not the same, with the retrieved 0.001 at $355 \mathrm{~nm}$ and 0.0005 at $532 \mathrm{~nm}$ for our case (Fig. 5 - bottom, right), the backscatter spectral dependence can be a combination of the effect that different factors have on the backscattered light, such as the size or shape of the dust particles.

Figure 5 shows good agreement between GARRLiC and AERONET retrievals (the latter is used in the LIRIC retrieval) within the GARRLiC retrieval uncertainties. Differences are seen only for the real part of the refractive index, 


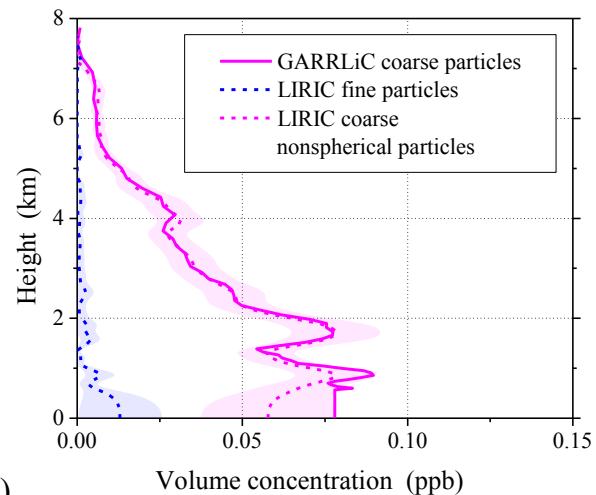

(a)

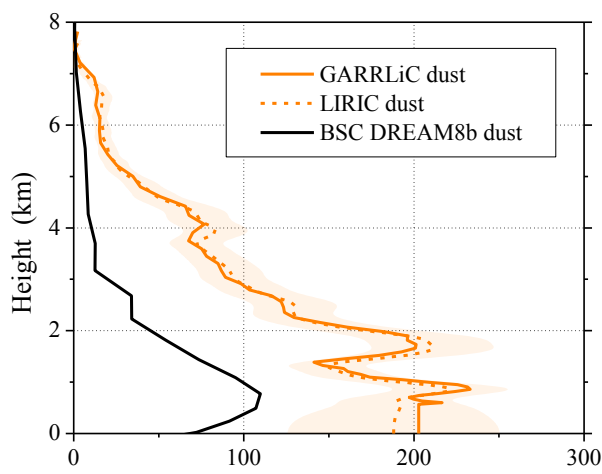

(b)

Mass concentration $\left(\mu \mathrm{g} \mathrm{m}^{-3}\right)$

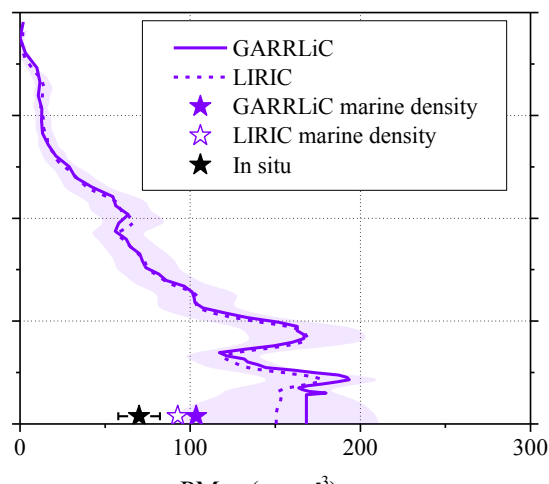

(c)

$\mathrm{PM}_{10}\left(\mu \mathrm{g} \mathrm{m}^{-3}\right)$

Figure 6. (a) Volume concentration profiles for GARRLiC coarse particles (pink) and LIRIC fine (dashed blue) and coarse non-spherical particles (dashed pink) at Finokalia, Crete on 26 June 2014, at 04:00-06:00 UTC. (b) Dust mass concentration profiles from GARRLiC (orange), LIRIC (dashed orange) and BSC-DREAM8b model (black) (the latter at 05:00 UTC). (c) PM 10 profiles from GARRLiC (purple) and LIRIC (dashed purple), along with their surface values, considering only marine particles at the surface ("GARRLiC marine density" and "LIRIC marine density" denoted by purple and white stars, respectively). The black star denotes the surface in situ measurements at 05:00-06:00 UTC (mean and time variability).

which for GARRLiC is at $\sim 1.45$, at the low end of the dust climatological value range of $1.48 \pm 0.05-1.56 \pm 0.03$ as reported in Dubovik et al. (2002). This value is much lower than the expected values for dust from western Sahara in situ measurements, at 1.55-1.65 (e.g. Kandler et al., 2007), and it may be due to the marine-particle mixture at lower heights, with the real part of the refractive index of $\sim 1.35$. The same is true for the low values of the imaginary part, due to the mixture of dust with the imaginary part, e.g. of 0.05 at $532 \mathrm{~nm}$ (e.g. Wagner et al., 2012), and marine particles with the imaginary part of $\sim 0.0005$ at $532 \mathrm{~nm}$ (e.g. Babin et al., 2003). Nevertheless, an important feature of the GARRLiC retrieval is the spectral dependence of the single-scattering albedo (SSA), showing the characteristic increase of dust absorption in the ultraviolet (Fig. 5, upper right) (Otto et al., 2007). Moreover, the GARRLiC size distribution agrees well with surface in situ SMPS measurements for the fine mode, showing a very small volume concentration for fine particles. The SMPS number size distribution is converted to $\mu \mathrm{m}^{3} \mu \mathrm{m}^{-2}$ for a direct comparison with the GARRLiC and
AERONET product, as described in Sect. 2.1.3. For this conversion we assume that mainly the first $2 \mathrm{~km}$ contain fine particles due to the mixing of marine and continental particles with dust there (Fig. 3b). Moreover, due to the low RH at the surface $(16 \%)$ we do not expect differences between the GARRLiC ambient size distribution and the SMPS dry measurements.

The concentration profiles from GARRLiC and LIRIC are in excellent agreement at heights $>1 \mathrm{~km}$, with differences less than $10 \%$ (Fig. 6a). LIRIC retrieves fine- and coarsemode profiles, whereas GARRLiC retrieves only one mode, dominated by coarse particles. The LIRIC coarse mode is only comprised of non-spherical particles. Figure $6 \mathrm{~b}$ shows the comparison of GARRLiC and LIRIC dust-particle profiles with the BSC-DREAM8b model. For this comparison we consider all particles in GARRLiC and LIRIC profiles to be dust particles. Furthermore, we multiply them with the dust density of $2.6 \mathrm{~g} \mathrm{~cm}^{-3}$ (Reid et al., 2003) to convert the volume concentration ratio (in ppb) to dust mass concentration (in $\mu \mathrm{g} \mathrm{m}^{-3}$ ). Although the shapes agree well, 


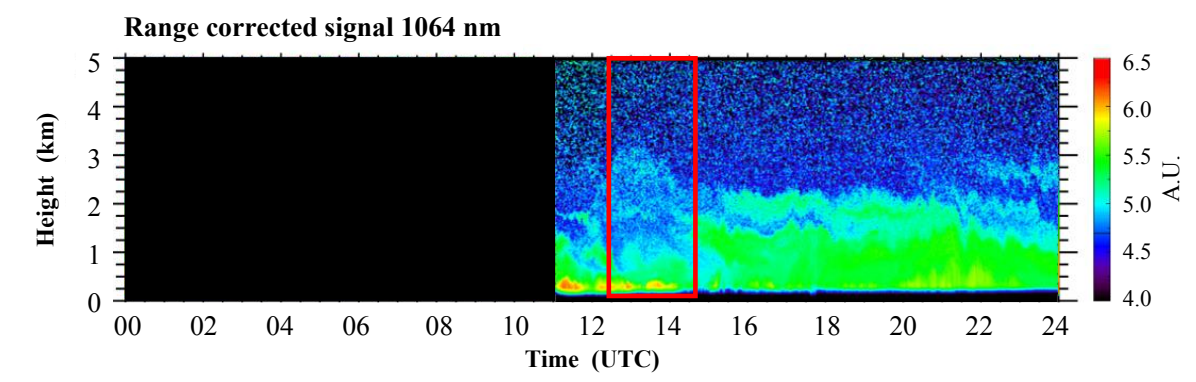

(a)

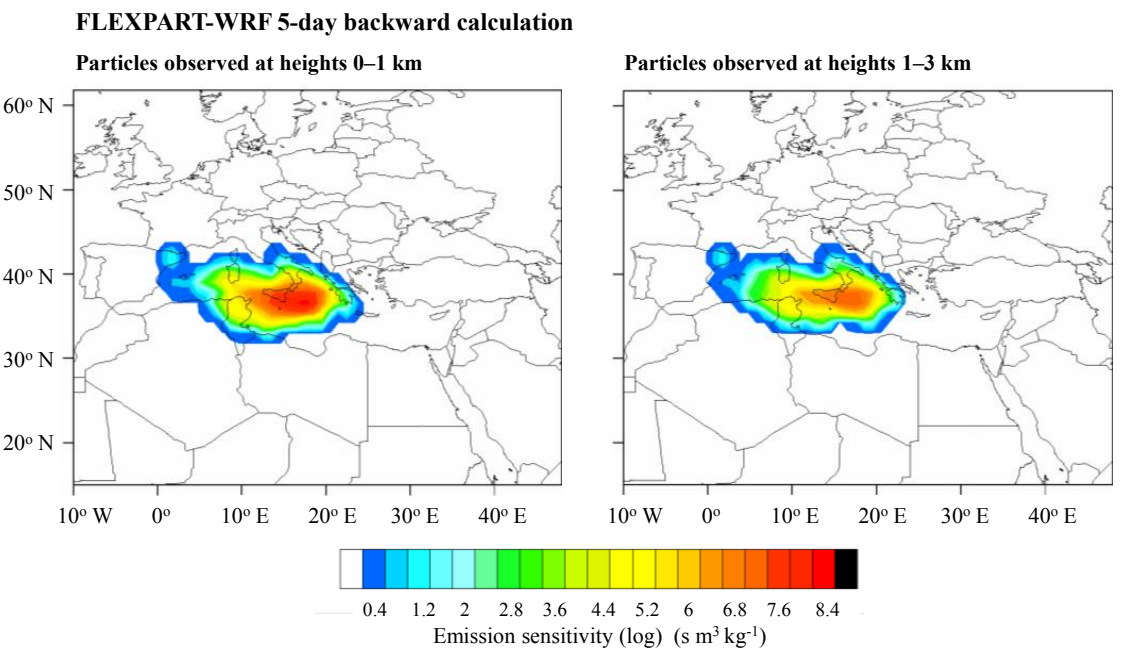

(b)

Figure 7. (a) Range-corrected backscattered signal at $1064 \mathrm{~nm}$ in arbitrary units from Polly XT OCEANET lidar at Finokalia, Crete on 15 July 2014. The red rectangle indicates the time range of the measurements used for the GARRLiC and LIRIC retrievals (12:3014:30 UTC). (b) Five-day backward FLEXPART-WRF calculation of emission sensitivity (i.e. residence time in the lowest $1 \mathrm{~km}$ in the atmosphere) in $\log \left(\mathrm{s} \mathrm{m}^{3} \mathrm{~kg}^{-1}\right)$ for the particles arriving at the layers 0-1 km (left) and 1-3 km (right) at 14:00 UTC.

the BSC-DREAM8b model values are lower than GARRLiC and LIRIC by a factor of 2. The BSC-DREAM8b underestimation when comparing to LIRIC is consistent with the findings of Binietoglou et al. (2015) for relatively low dust concentrations (as is the case here). The underestimation is shown in the BSC-DREAM8b dust AOD at $550 \mathrm{~nm}$ as well, with a value of $\sim 0.2$, which is half of the sun-photometermeasured AOD at $500 \mathrm{~nm}$, of 0.4 . When we scale the BSCDREAM8b concentration with these AOD values (multiplying by a factor of 2) the bias is reduced to less than $10 \%$ at $1 \mathrm{~km}$ and $50 \%$ at $3 \mathrm{~km}$, relative to GARRLiC and LIRIC concentrations. The GARRLiC and LIRIC mass concentrations are also compared with surface in situ $\mathrm{PM}_{10}$ measurements, showing the algorithms overestimating the particle concentration at the surface level (Fig. 6c). We calculate the $\mathrm{PM}_{10}$ concentrations from GARRLiC and LIRIC mass concentrations as percentages of the particles with diameters less than $10 \mu \mathrm{m}$ (i.e. 83 and $80 \%$ of the total mass, respectively). Figure $6 \mathrm{c}$ shows the GARRLiC and LIRIC PM 10 surface values (purple stars in plot) for marine instead of dust particles at the surface, thus using the marine-particle density for the volume to mass conversion (i.e. $1.7 \mathrm{~g} \mathrm{~cm}^{-3}$ for dry marine particles
(Stock et al., 2011), since the measured RH at the surface is $16 \%$ ). The agreement with the surface in situ measurements is better now, but it is only indicative, since what we have at the surface is most probably a mixture of marine, continental and dust particles as shown in Fig. 3b.

To summarize, the GARRLiC and LIRIC retrievals perform well for the dust episode on 26 July, considering the consistency with the Klett retrievals, the BSC-DREAM8b modelled mass concentration profiles and the surface in situ measurements of the fine-mode size distribution, as well as the expected increase of the dust absorption in the ultraviolet. The discrepancies seen for the retrieval closer to the surface and the $\mathrm{PM}_{10}$ at the surface level can be explained if we consider the incomplete lidar information in the overlap region.

\subsection{Marine and polluted continental particle case}

On 15 July the lidar measurements at 12:30-14:30 UTC showed a low-AOD layer of non-depolarizing particles extending up to $3 \mathrm{~km}$ (Fig. 7a). The lack of depolarization indicates spherical (hydrated) marine particles, which is also supported by our source-receptor analysis (Fig. 7b). Specif- 


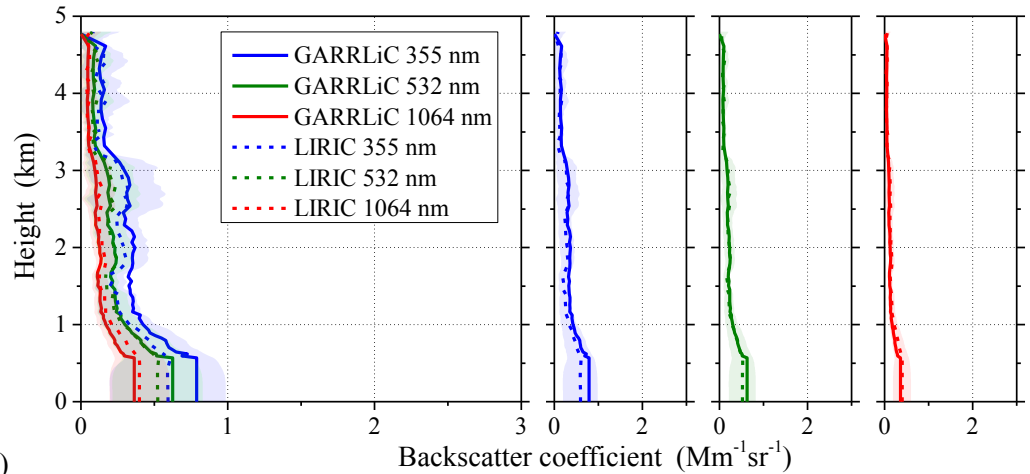

(a)
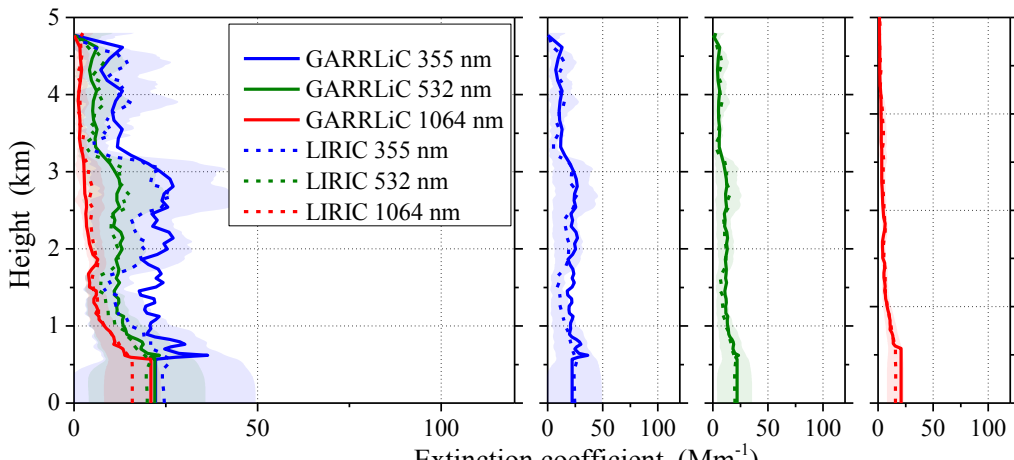

(b) Extinction coefficient $\left(\mathrm{Mm}^{-1}\right)$
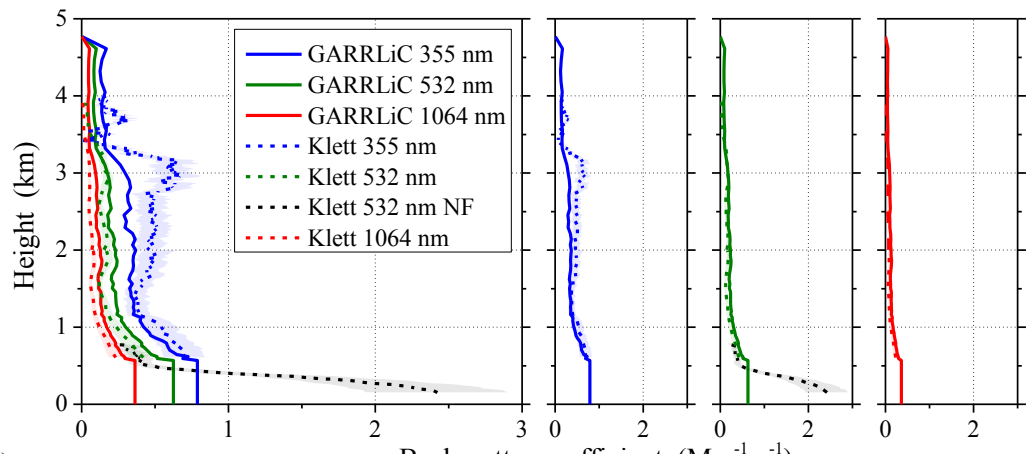

(c)

Backscatter coefficient $\left(\mathrm{Mm}^{-1} \mathrm{sr}^{-1}\right)$

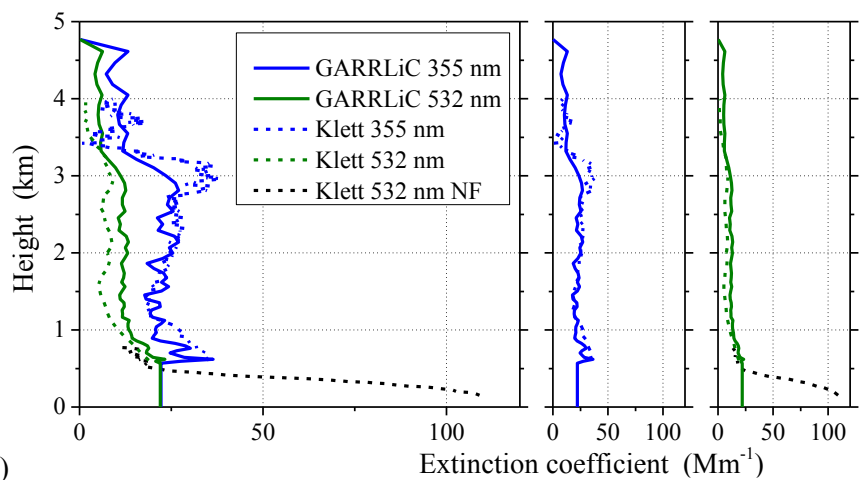

Figure 8. As in Fig. 4 but for backscatter and extinction coefficient retrievals at Finokalia, Crete on 15 July 2014, at 12:30-14:30 UTC. 

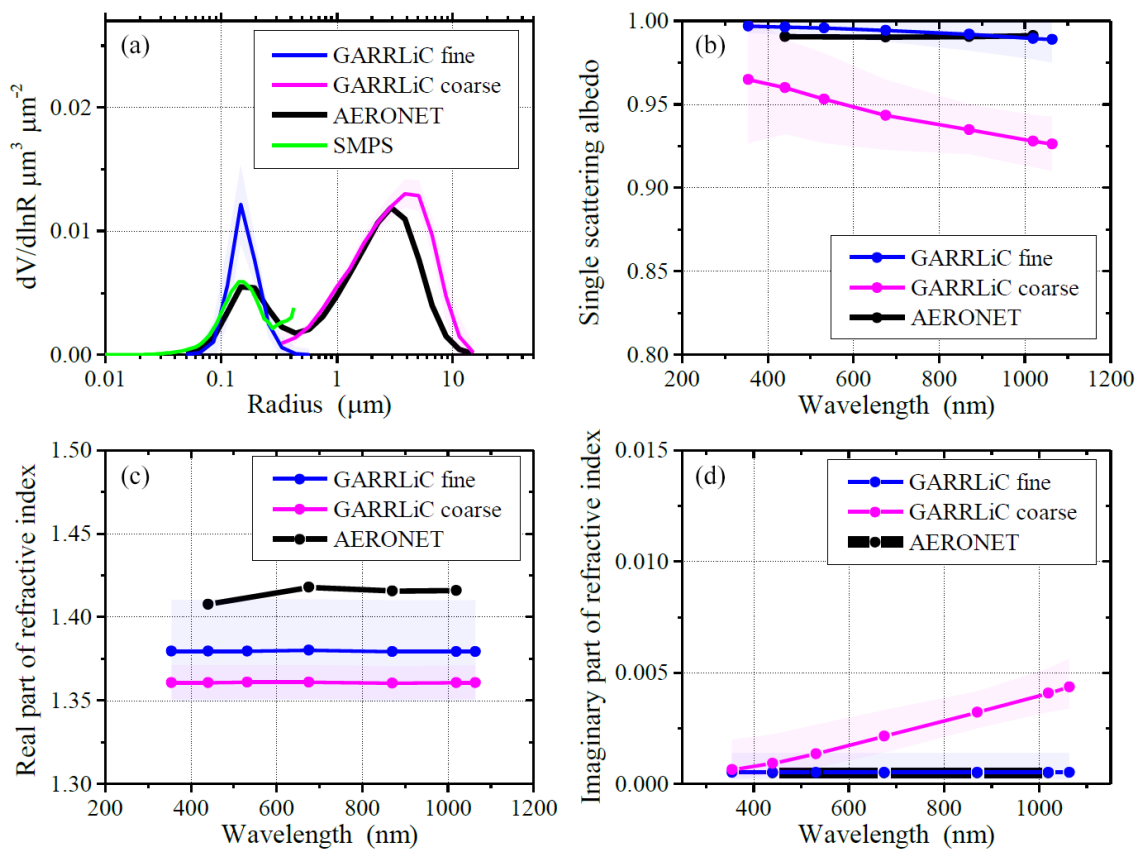

Figure 9. GARRLiC retrievals for fine (blue) and coarse particles (pink) of size distribution (a), spectral SSA (b), spectral real and imaginary part of the refractive index (c, d) at Finokalia, Crete on 15 July 2014, at 12:30-14:30 UTC. The black line shows the AERONET retrieval at 13:24 UTC (also used in LIRIC). The green line in the size distribution plot (a) is the mean value of the surface in situ SMPS measurements at 12:00-13:20 UTC.

ically, FLEXPART-WRF simulations show that the particles above Finokalia Station mainly have a marine origin along the whole atmospheric column, with a possible contribution of continental aerosol from southern Italy. This scenario is further supported by AERONET measurements at 13:24 UTC of low AOD of $\sim 0.06$ at $500 \mathrm{~nm}$, high Ångstrom exponent of $\sim 1.2$ at $440 / 870 \mathrm{~nm}$ and low refractive index of $\sim 1.4+i 0.0005$ at $440 \mathrm{~nm}$, which are within the climatological value ranges for marine particles and their mixtures, as reported by Dubovik et al. (2002).

The low AOD is unfavourable for the GARRLiC and AERONET microphysical property retrievals, especially for the spectral refractive index and SSA (Dubovik et al., 2000; Lopatin et al., 2013). The latter requires an AOD of at least 0.4 at $440 \mathrm{~nm}$ for satisfactory accuracy in the case of sunphotometer-only retrieval (Dubovik et al., 2000). The lidar information combined with the sun-photometer measurements in GARRLiC is expected to improve the retrieval for low-AOD cases (Lopatin et al., 2013). Although the AOD requirements have not been quantified yet for GARRLiC, an AOD of 0.3 at $440 \mathrm{~nm}$ is considered sufficient. As reported in Dubovik et al. (2002), the marine particles rarely exceed the AOD of 0.15 at $440 \mathrm{~nm}$; thus we do not expect a highly accurate refractive index and SSA retrievals from GARRLiC or from AERONET/LIRIC for the marine particles. Furthermore, the marine case analysed here has a much lower AOD; thus we consider the refractive index and SSA retrievals to be only indicative in this case. In addition, as seen in Fig. 7a, most of the aerosol load is located below $1 \mathrm{~km}$, where the lidar incomplete-overlap region is located, which challenges the combined lidar-sun-photometer retrieval even more.

The GARRLiC and LIRIC retrievals used the lidar measurements at 12:30-14:30 UTC (red box in Fig. 7a) and the sun-photometer measurements at 13:24 UTC. Figure 8 shows the retrieved backscatter and extinction coefficients at 355 , 532 and $1064 \mathrm{~nm}$, and the corresponding retrievals from the Klett method. For the latter we use LRs of 50, 45 and $45 \mathrm{sr}$ for 355,532 and 1064, which closely reproduce the sunphotometer-measured AODs of 0.1, 0.05 and 0.02 at 340, 500 and $1020 \mathrm{~nm}$. The agreement between GARRLiC and LIRIC is satisfactory within the LIRIC uncertainties (Fig. 8a and b). Above $550 \mathrm{~m}$, this is also the case for GARRLiC and Klett backscatter coefficient retrievals, whereas for the extinction coefficients the differences are within $30 \%$ for $355 \mathrm{~nm}$ and $10-40 \%$ for $532 \mathrm{~nm}$ relative to GARRLiC values (Fig. $8 \mathrm{c}$ and d). In the marine boundary layer (below $550 \mathrm{~m}$ ) the Klett $\mathrm{NF}$ backscatter and extinction coefficients at $532 \mathrm{~nm}$ show much larger values than the ones retrieved from GARRLiC and LIRIC. This very vividly highlights the importance of the NF measurements in properly retrieving the marine-particle properties with lidars.

GARRLiC retrieves both fine and coarse particles in this case, which we consider to be mainly of continental and marine origin, respectively. The fine-particle volume size distribution shows $\sim 10 \%$ more volume than the AERONET product and the surface in situ SMPS measurements (Fig. 9, 


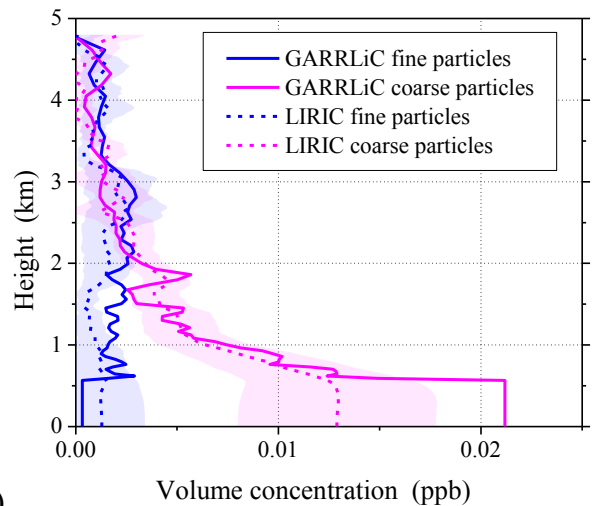

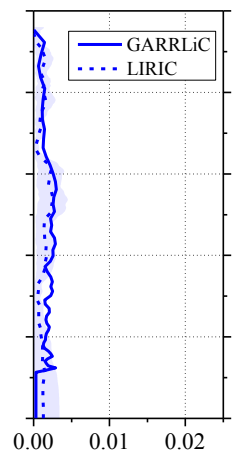

Vol. conc. fine (ppb)

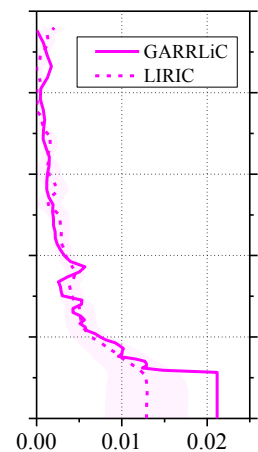

Vol. conc. coarse (ppb)

(a)

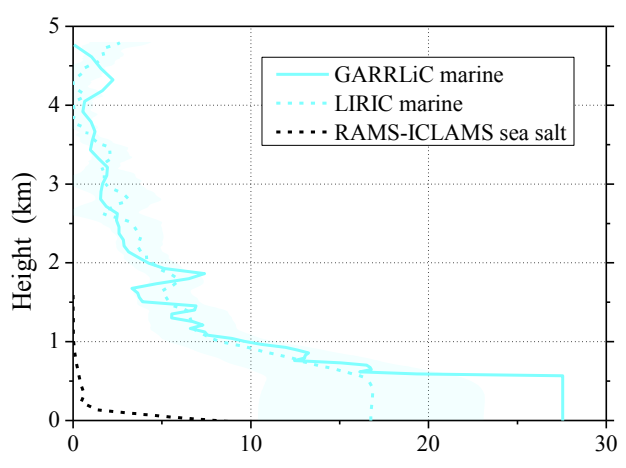

(b)

Mass concentration $\left(\mu \mathrm{g} \mathrm{m}^{-3}\right)$

(c)

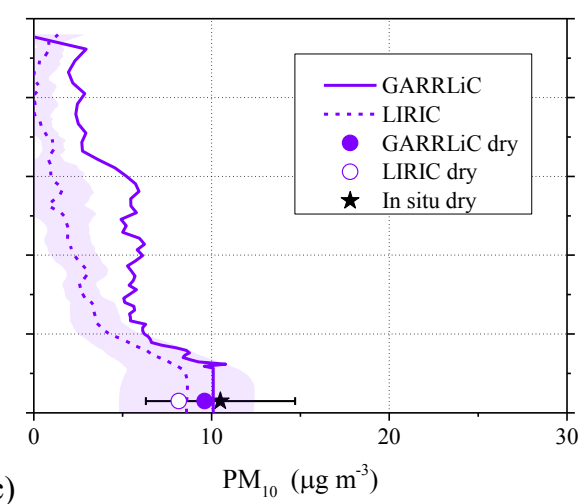

Figure 10. (a) Volume concentration profiles for GARRLiC fine (blue) and coarse particles (pink) and LIRIC fine (dashed blue) and coarse spherical particles (dashed pink) at Finokalia, Crete on 15 July 2014, at 12:30-14:30 UTC. (b) GARRLiC (light blue) and LIRIC (dashed light blue) marine-particle mass concentration profiles, along with the RAMS-ICLAMS sea salt mass concentration profile (black) at 13:00 UTC. (c) $\mathrm{PM}_{10}$ profiles from GARRLiC (purple) and LIRIC (dashed purple), along with the dry GARRLiC and LIRIC PM 10 at the surface (purple and white circles, respectively). The black star denotes the in situ $\mathrm{PM}_{10}$ measurements at 04:00-05:00 UTC (mean and time variability).

upper left). The SMPS volume size distribution is converted to $\mu \mathrm{m}^{3} \mu \mathrm{m}^{-2}$ assuming that most particles reside from the surface up to $\sim 1 \mathrm{~km}$ (Fig. 7). The difference may be partly due to the instrument drying the particle sample, but the effect is not expected to be that strong since the $\mathrm{RH}$ at the surface is $60 \%$ and the corresponding hygroscopic growth is estimated at 1.17 (Sect. 2.1.3, Eq. 2). For the coarse mode, GARRLiC retrieves $\sim 50 \%$ more volume than AERONET. The AERONET SSA and spectral refractive index retrievals are the same with the GARRLiC finemode retrievals or within the retrieval uncertainty (Fig. 9). These high values of SSA (close to 1) and the refractive index of $1.38 \pm 0.4+i 0.0005 \pm 0.0003$ are within the range of climatological values of continental particles, according to Dubovik et al. (2002). For the GARRLiC coarse mode, the SSA and imaginary part of the refractive index show very high values for marine particles, which are most probably false, whereas the real part of the refractive index of $\sim 1.36$ agrees well with the climatological value of $1.36 \pm 0.01$ for marine particles (Dubovik et al., 2002).
Figure 10a shows the GARRLiC and LIRIC volume concentration profiles, which agree well within the LIRIC retrieval uncertainties above $550 \mathrm{~m}$, whereas below the GARRLiC concentration for the coarse particles is larger. Assuming that the marine particles are comprised only of coarse particles, we derive the marine mass concentration profiles from GARRLiC and LIRIC as shown in Fig. 10b. The mass concentration profiles are calculated from the coarse volume concentration profiles using a sea salt density of $1.3 \mathrm{~g} \mathrm{~cm}^{-3}$. This value denotes the density of a sea salt solution at a RH of 50-60\% (Eq. 3 in Zhang et al., 2005), with the RH values provided by the RAMS model. Figure $10 \mathrm{~b}$ also shows the RAMS-ICLAMS sea salt model mass concentration profile which presents lower values than GARRLiC and LIRIC, with differences of $\sim 80$ and $60 \%$ at the surface, respectively. Moreover, GARRLiC and LIRIC PM 10 mass concentrations seem to agree well with the surface in situ $\mathrm{PM}_{10}$ measurements (Fig. 10c) within the time variability of the latter. The GARRLiC and LIRIC $\mathrm{PM}_{10}$ values are calculated using the respective percentages of volume size distributions for particles with diameters less than $10 \mu \mathrm{m}$ (i.e. the sum of fine-mode 

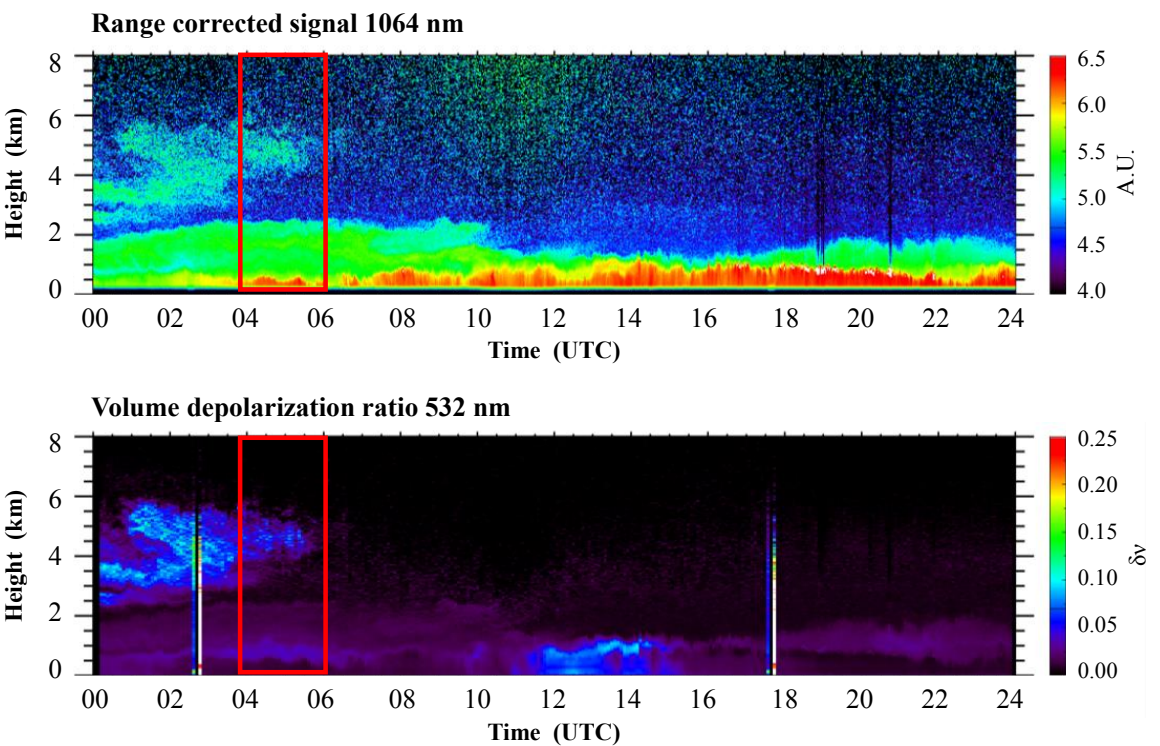

(a)

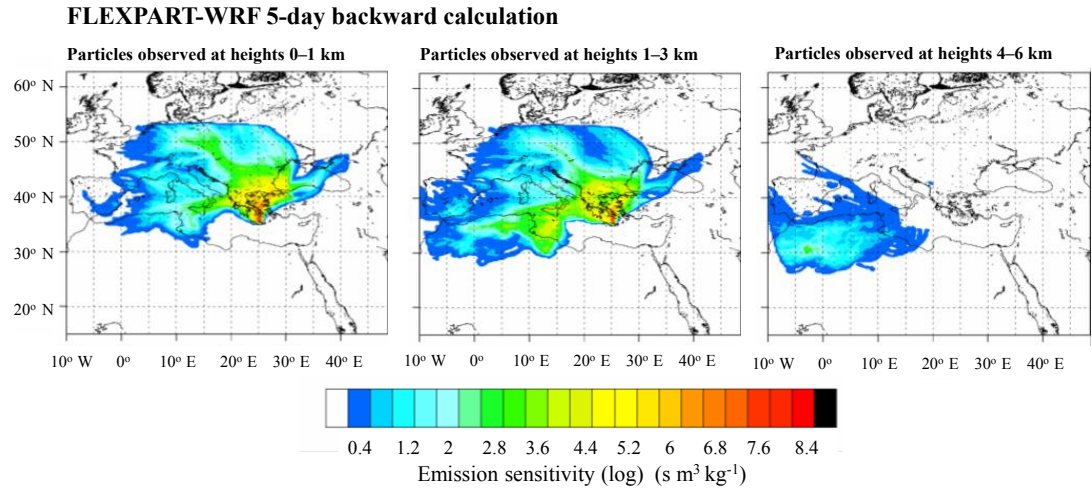

Figure 11. (a) Range-corrected backscattered signal at $1064 \mathrm{~nm}$ in arbitrary units (top) and volume depolarization ratio at $532 \mathrm{~nm}$ (bottom) from Polly ${ }^{\text {XT }}$ OCEANET lidar at Finokalia, Crete on 4 July 2014. The red rectangle indicates the GARRLiC and LIRIC retrievals (04:0006:00 UTC). (b) Five-day backward FLEXPART-WRF calculation of emission sensitivity (i.e. residence time in the lowest $1 \mathrm{~km}$ in the atmosphere) in $\log \left(\mathrm{s} \mathrm{m}^{3} \mathrm{~kg}^{-1}\right)$ for the particles arriving at heights 0-1 km (left), 1-3 km (middle) and 4-6 km (right), at 07:00 UTC.

volume and $35 \%$ of coarse-mode volume for GARRLiC and $50 \%$ of the total volume for AERONET/LIRIC). The comparison with the in situ measurements should also consider the drying of the ambient sample with the in situ instrument. We calculate the GARRLiC and LIRIC dry $\mathrm{PM}_{10}$, using a hygroscopic growth factor of 1.17 at $\mathrm{RH}=60 \%$ at the surface (Eq. 2). These dry values agree well with the in situ measurements, within their time variability.

To summarize, GARRLiC retrieves more fine particles than AERONET and surface in situ measurements. The fineparticle SSA and refractive index are characteristic of continental particles. The corresponding coarse-mode retrieval probably fails for SSA and the imaginary part of the refractive index, which are very difficult to retrieve with low AODs, but the real part of the refractive index properly assigns the refractive index of marine particles. Both GARRLiC and LIRIC concentration profiles seem to agree well with the $\mathrm{PM}_{10}$ surface in situ measurements. Since the marinedominated scenes usually have very low AOD and low vertical extent (Ho et al., 2015), it is challenging to obtain trustworthy retrievals from GARRLiC and LIRIC for marineparticle scenes. One way to improve the marine retrievals in future efforts is to try to increase the lidar information in the overlap region, utilizing, for example, the NF lidar measurements, as discussed in Sect. 3.1.1.

\subsection{Dust and marine case}

On 4 July a mixture of dust, marine and continental aerosols was observed at Finokalia Station. Figure 11a shows an advected depolarizing dust plume at $4-6 \mathrm{~km}$ and a less depolarizing plume extending from the ground up to $2-3 \mathrm{~km}$ at 04:00-06:00 UTC, with volume depolarization ratios at 

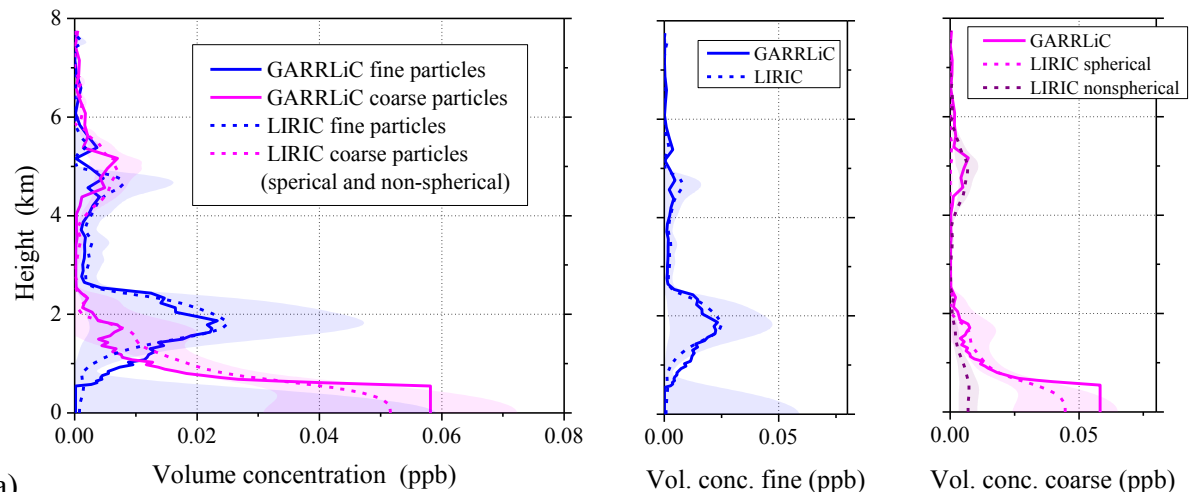

(a)
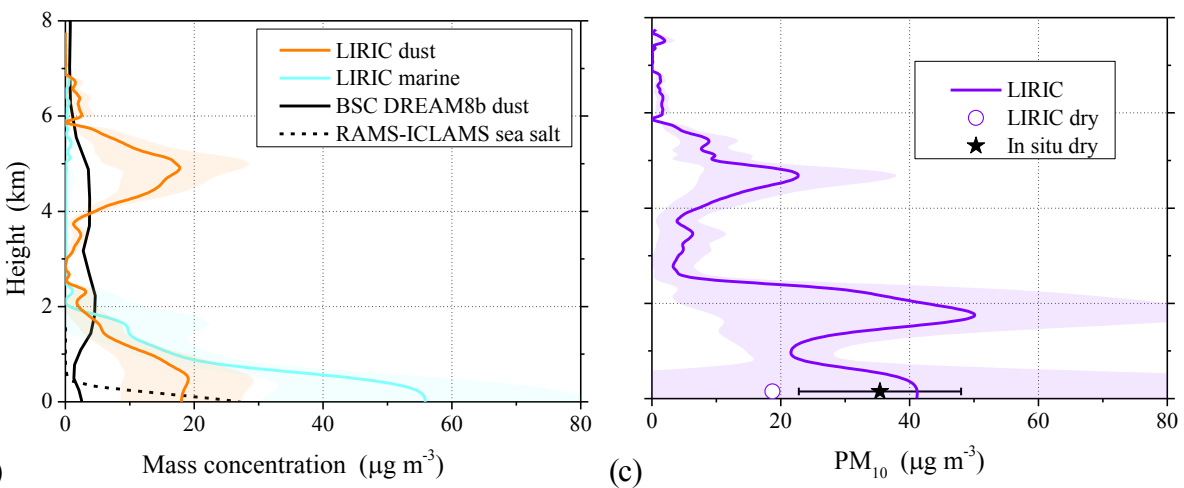

Figure 12. (a) Left: volume concentration profiles for GARRLiC fine (blue) and coarse particles (pink) and LIRIC fine (dashed blue) and total coarse particles (dashed pink) at Finokalia, Crete on 4 July 2014, at 04:00-06:00 UTC. Middle: volume concentration of fine particles from GARRLiC (blue) and LIRIC (dashed blue). Right: volume concentration of coarse particles from GARRLiC (pink) and LIRIC, disentangled in the spherical (dashed pink) and non-spherical (dashed purple) components. (b) Mass concentration profiles for LIRIC dust (orange) and marine particles (light blue), along with the modelled dust (black) and sea salt (dashed black) particle concentration profiles (both at 05:00 UTC). (c) $\mathrm{PM}_{10}$ profile from LIRIC (purple), along with the dry LIRIC $\mathrm{PM}_{10}$ at the surface (white circle). The black star denotes the surface in situ $\mathrm{PM}_{10}$ measurements at 04:00-05:00 UTC (mean and time variability).

$532 \mathrm{~nm}$ of 0.1 and $<0.05$, respectively. This is a weak dust episode, with a measured column AOD of $\sim 0.15$ at $500 \mathrm{~nm}$, which according to the AERONET and GARRLiC uncertainty standards discussed in Sect. 4.2 should not be sufficient for a full characterization of the particles. The dustand marine-particle transport systems are supported by the BSC-DREAM8b dust model and RAMS-ICLAMS sea salt model simulations (Fig. 12b), respectively, as well as by our FLEXPART-WRF source-receptor calculations (Fig. 11b). The latter show mainly Saharan dust particles at 4-6 km, marine particles mostly from the Aegean Sea along with continental particles from the Balkans up to $1 \mathrm{~km}$ and a mixture of marine, continental and dust particles at $1-3 \mathrm{~km}$.

GARRLiC retrieves these three layers (Fig. 12a), but it cannot characterize them effectively in terms of their refractive indices, since it is able to retrieve only one refractive index for each mode. For example, the coarse mode of the dust-marine mixture contains dust particles with a real part of refractive index of $\sim 1.55-1.65$ (e.g. Kandler et al., 2007) together with marine particles of quite a different refractive index, with a real part of $\sim 1.35$ (Dubovik et al., 2002). Thus, what we get from GARRLiC as the refractive index of the coarse mode mixture is possibly closer to an average of the refractive indices of dust and marine particles. This is shown in Fig. 13 (bottom right), with the GARRLiC coarse-mode refractive index having a value of 1.45 for the real part. The imaginary part of the coarse mode and the SSA show an unusual increase and decrease, respectively, towards the longer wavelengths, which is most probably false. The fine mode should contain mostly continental particles, but the retrieved refractive index of $1.36+i 0.001$ is more characteristic of marine particles (Dubovik et al., 2002). The AERONET retrieval (used in LIRIC algorithm) assigns a marine refractive index $(\sim 1.35+i 0.0005)$ to both fine and coarse particles. The fine-mode size distribution compares well with AERONET but presents slightly lower values than SMPS surface in situ measurements (Fig. 13, upper left). With a surface RH of $75 \%$, corresponding to a hygroscopic growth factor of 1.3 (Eq. 2), the GARRLiC fine-particle size distri- 

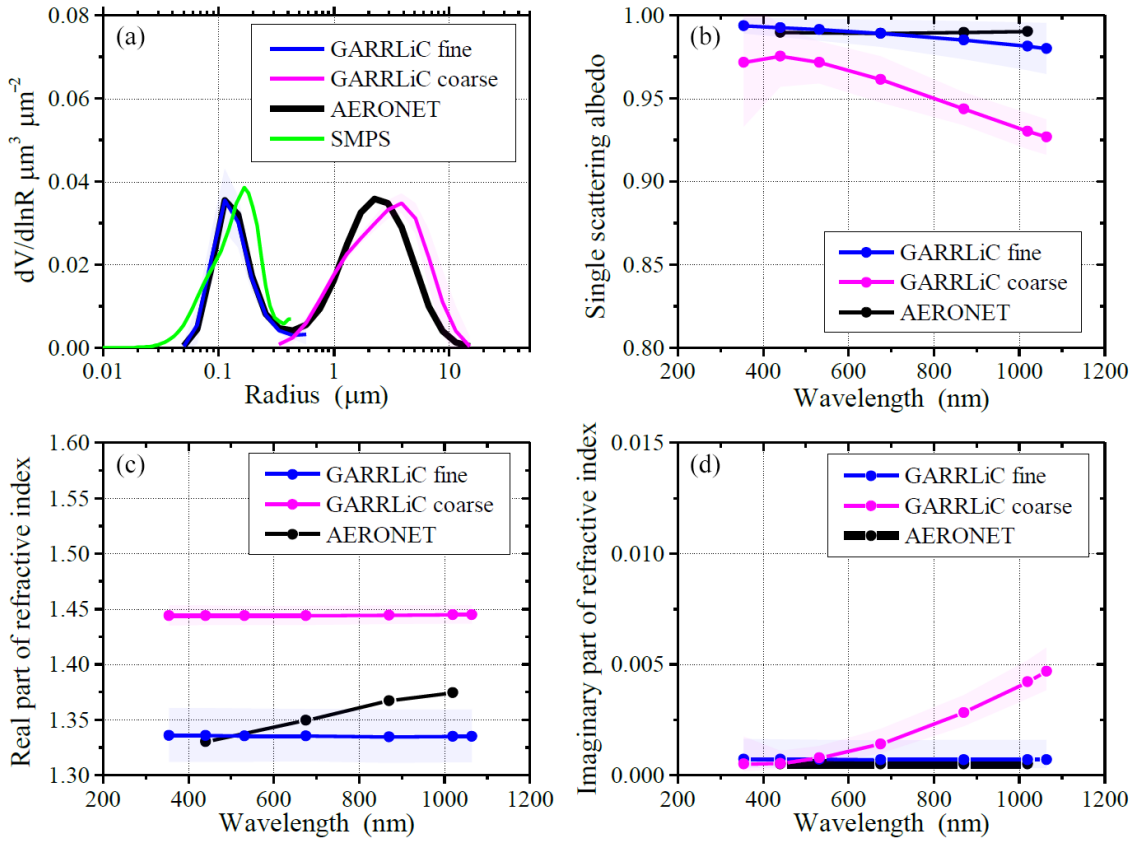

Figure 13. GARRLiC retrievals for fine (blue) and coarse particles (pink) of size distribution (a), spectral SSA (b), spectral real and imaginary part of the refractive index (c, d) at Finokalia, Crete on 4 July 2014, at 04:00-06:00 UTC. The black line shows the AERONET retrieval at 05:49 UTC (also used in LIRIC). The green line in the size distribution plot (a) is the mean value of the surface in situ SMPS measurements at 04:00-06:00 UTC.
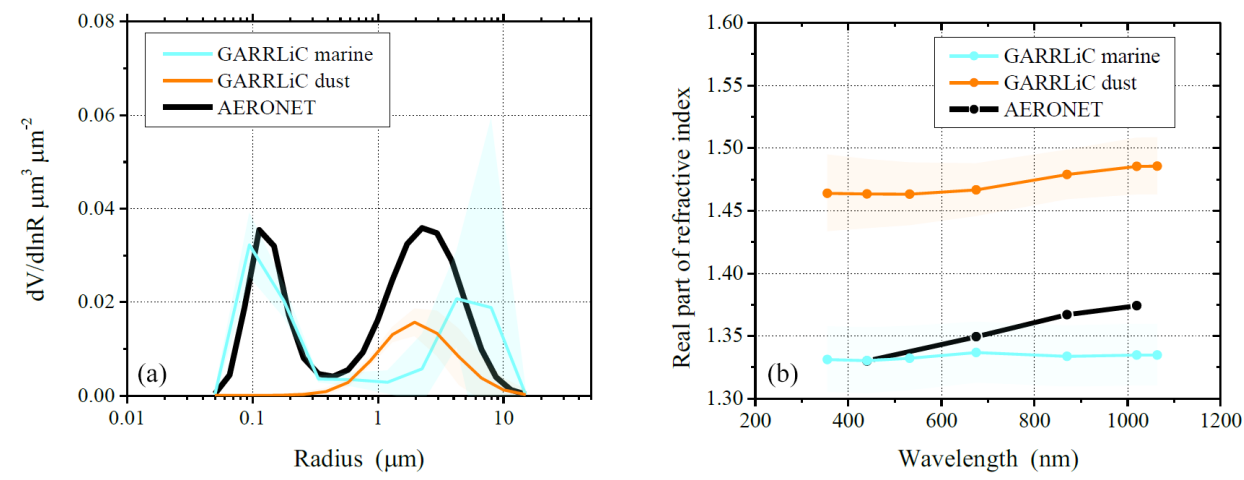

Figure 14. Potential of GARRLiC to retrieve marine- (light blue) and dust-particle (orange) size distribution (left) and spectral real part of the refractive index (right). The retrieval refers to measurements at Finokalia, Crete on 4 July 2014, at 04:00-06:00 UTC. The black line shows the AERONET retrieval at 05:49 UTC.

bution should be larger than the SMPS dried-particle measurements.

Figure 14 shows the potential of GARRLiC to retrieve the marine and dust components of the mixture by changing the definition of the two modes retrieved: instead of fine and coarse mode, GARRLiC is set to retrieve two modes that span the whole size range so that both contain coarse particles. It derives a dust mode that contains only coarse particles and a marine mode that contains both fine and coarse particles, larger than those of dust. Raptis et al. (2015) showed similar results for the marine and dust size distributions using their multimodal analysis for a different dust-marine mixture case during the CHARADMExp campaign. The retrieved real part of the refractive index is $\sim 1.33$ for marine particles and $\sim 1.47$ for dust particles. Although these values are very close to the climatological values for marine and dust particles, the retrievals of the imaginary part of the refractive index and the volume concentration profiles are not satisfactory (not shown here). We believe that these results show a potential for successful marine-dust mixture characterization from GARRLiC in the future if the new versions of the algorithm utilize the cross-polarized signals as well. As in LIRIC, the polarization measurements will help to derive the 
spherical (marine) and non-spherical (dust) components of the mixture.

LIRIC provides the dust and marine vertical distribution, since it disentangles the coarse-particle volume concentration profile into its spherical (marine) and non-spherical (dust) components (Fig. 12a, right). Assuming a very low contribution from dust and marine particles in the fine mode we acquire the marine and dust concentration profiles from the spherical and non-spherical coarse-particle concentration profiles, respectively. Figure $12 \mathrm{~b}$ shows that LIRIC marine and dust mass concentration profiles have larger values than the BSC-DREAM8b dust and the RAMS-ICLAMS sea salt models, respectively. In order to acquire the mass concentration profiles, LIRIC dust and marine volume profiles are multiplied with the density values of $2.6 \mathrm{~g} \mathrm{~cm}^{-3}$ (Reid et al., 2003) and $1.25 \mathrm{~g} \mathrm{~cm}^{-3}$, respectively. The marineparticle density corresponds to $60-80 \% \mathrm{RH}$ (Zhang et al., 2005), as this is provided by the RAMS model at $0-1 \mathrm{~km}$. We believe that the BSC-DREAM8b model underestimates the dust concentration, similarly to the dust case in Sect. 4.1, since the model AOD of $\sim 0.025$ at $500 \mathrm{~nm}$ is approximately five times lower than the sun-photometer-measured AOD at $550 \mathrm{~nm}$ (not taking into account the AOD contribution of the marine and continental particles). By multiplying the BSCDREAM8b dust profile by 5 we get a better agreement with the LIRIC dust profile at $4-6 \mathrm{~km}$, but in the mixed layer at 0 $3 \mathrm{~km}$ this agreement is not satisfactory (not shown here). The RAMS-ICLAMS model shows lower sea salt concentration than LIRIC (as in Sect. 4.2), with differences of $\sim 60 \%$ at the surface level. Figure $12 \mathrm{c}$ shows that LIRIC PM $_{10}$ values agree well with the surface in situ measurements, within the time variability of the latter. The LIRIC $\mathrm{PM}_{10}$ is calculated using the volume percentage of the particles with diameter less than $10 \mu \mathrm{m}$ (i.e. $60 \%$ of the total volume). Moreover, we calculate the LIRIC dry PM $_{10}$ using Eq. (1) and a particle hygroscopic growth of 1.3 for $\mathrm{RH}=75 \%$ at the surface (Eq. 2). The LIRIC dry $\mathrm{PM}_{10}$ is lower than the surface in situ measurements, at $\sim 50 \%$ of their mean value. For GARRLiC the $\mathrm{PM}_{10}$ profile cannot be calculated, since the corresponding volume concentration profile is a mixture of dust, marine and continental particles with unknown density.

Figure 15 shows the backscatter and extinction coefficients retrieved with GARRLiC, LIRIC and Klett methods. GARRLiC and LIRIC agree well within the LIRIC uncertainties (Fig. 15a and b). The agreement with Klett retrievals is satisfactory for the backscatter coefficients at 532 and $1064 \mathrm{~nm}$ above $550 \mathrm{~m}$, within their uncertainties, with differences of $60-130 \%$ seen for the $355 \mathrm{~nm}$ retrieval (Fig. 15c). As for the marine case in Sect. 4.2, the NF backscatter coefficient at $532 \mathrm{~nm}$ shows much larger values. The same holds for the $\mathrm{NF}$ extinction coefficient at $532 \mathrm{~nm}$ (Fig. 15d). The Klett extinction coefficients at $1-3 \mathrm{~km}$ are up to 60 and $50 \%$ lower than GARRLiC at 355 and $532 \mathrm{~nm}$.

Overall, this is a challenging case for both the GARRLiC and LIRIC algorithms. We can claim that GARRLiC shows some potential in providing a successful dust and marine microphysical property characterization when more information (e.g. cross-polarized lidar signals) is included in the retrieval. Moreover, the LIRIC capability of providing the vertical distribution of dust and marine particles is mostly successful when the results are compared with our sourcereceptor simulations and the surface in situ $\mathrm{PM}_{10}$ measurements. As is the case for the marine-particle characterization in Sect. 4.2, we believe that this retrieval will benefit greatly from NF measurements.

\section{Summary and conclusions}

GARRLiC and LIRIC algorithms provide the great innovation of retrieving the vertical distribution of aerosol microphysics utilizing the synergy of the elastic backscatter lidar and sun-photometer techniques. This way, the algorithms show the potential to effectively characterize the vertical distribution of fine, coarse spherical and coarse non-spherical particle concentrations in the case of LIRIC, and the concentration profiles of fine and coarse particles, along with their column-averaged size, shape and spectral refractive index, in the case of GARRLiC.

In this study we used both algorithms to characterize three cases of dust and marine presence during the ESACHARADMExp experimental campaign. For the first case GARRLiC achieves a successful retrieval of the dust vertical distribution and microphysical characterization, which agrees well with AERONET and climatological values for dust within the respective uncertainties. Both LIRIC and GARRLiC concentration profiles are found to be consistent with the BSC DREAM8b dust vertical structure, showing up to $100 \%$ larger values than the surface in situ $\mathrm{PM}_{10}$ measurements. For the second case, consisting of mainly marine particles, both algorithms provide satisfactory concentration retrievals, well within the time variability of the surface in situ $\mathrm{PM}_{10}$ measurements. The GARRLiC microphysical property retrieval is mostly not successful for the marine particles, with $\sim 10 \%$ more fine-particle volume than the AERONET product and the surface in situ measurements. This is due to the difficulties posed by the very low AOD and the insufficient lidar information in the overlap region, where most of the marine aerosol load resides. Lastly, for the more challenging case of dust and marine mixture, LIRIC provides the dust and marine-particle vertical structure due to its capability to retrieve the coarse-mode spherical (marine) and nonspherical (dust) components. GARRLiC shows potential in disentangling the marine and dust components if more information is included in the algorithm input.

The difficulties posed in retrieving the concentration profiles and the microphysical properties of dust and marineparticle mixtures in the atmospheric column have to do with the low AOD of the marine plumes, the insufficient lidar information in the overlap region and the number of modes 

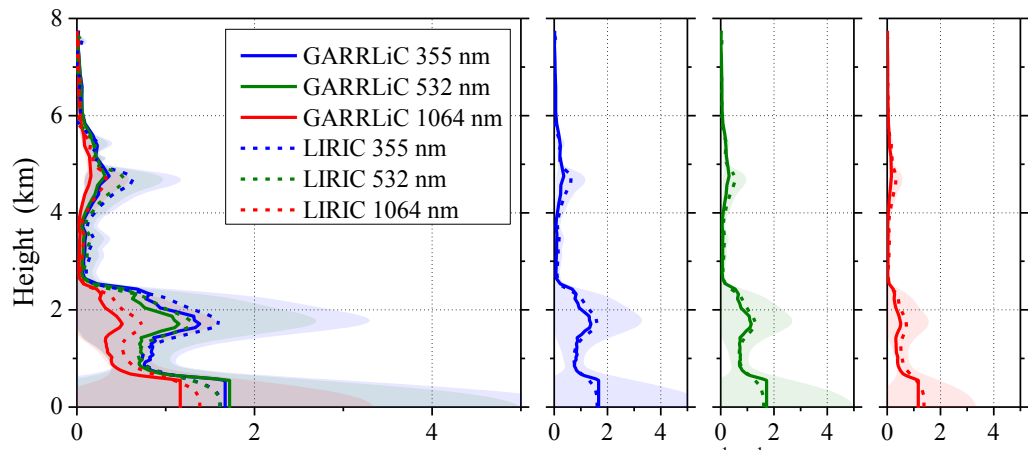

(a)

Backscatter coefficient $\left(\mathrm{Mm}^{-1} \mathrm{sr}^{-1}\right)$
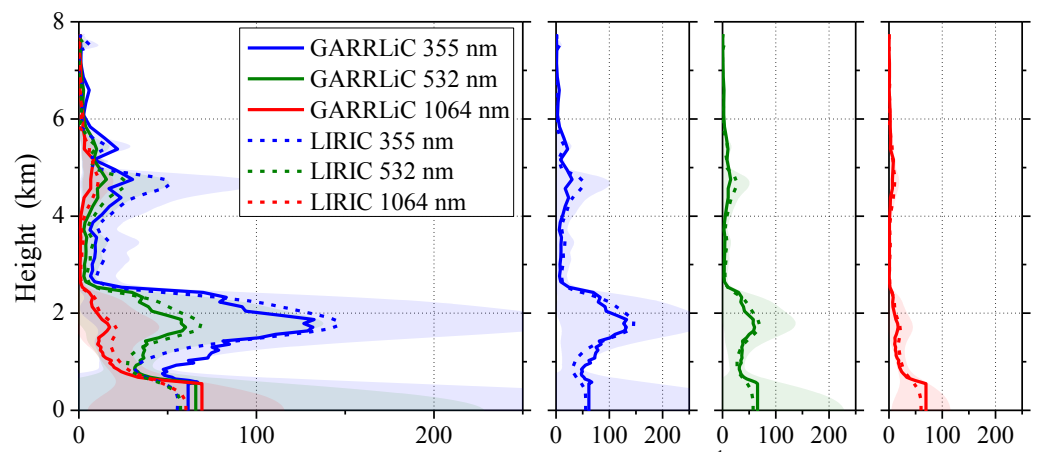

(b)

Extinction coefficient $\left(\mathrm{Mm}^{-1}\right)$
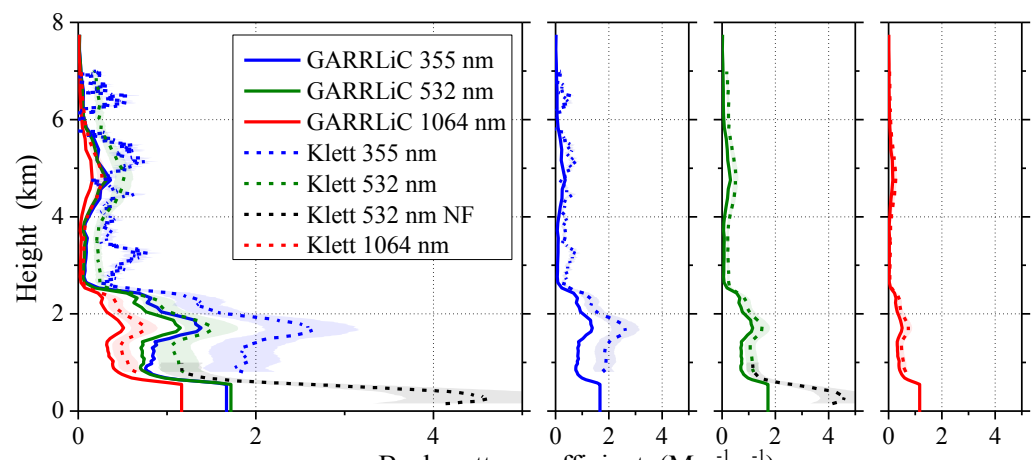

(c)

Backscatter coefficient $\left(\mathrm{Mm}^{-1} \mathrm{sr}^{-1}\right)$

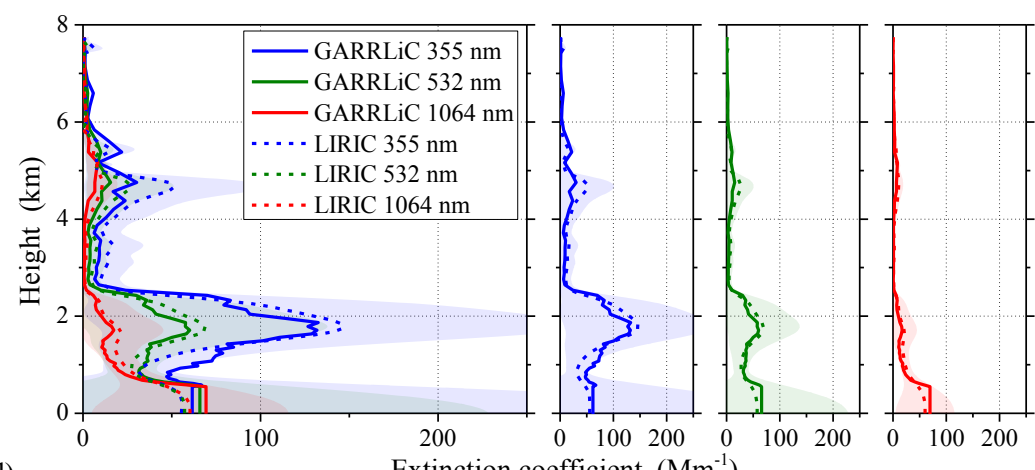

(d)

Extinction coefficient $\left(\mathrm{Mm}^{-1}\right)$

Figure 15. As in Fig. 4 but for backscatter and extinction coefficient retrievals at Finokalia, Crete on 4 July 2014, at 04:00-06:00 UTC. 
from the retrievals. For GARRLiC, the retrieval of multiple modes would be possibly feasible in the future with the incorporation of polarimetric measurements from the sun-photometer and/or the cross-polarized and Raman signals from the lidar. Moreover, we could try to increase the near-surface information from the lidar by performing the signal gluing technique between the FF and NF measurements and/or by using additional information available from in situ observations. We aim to continue investigating the GARRLiC and LIRIC potential for aerosol characterization and follow related improvements in the framework of the ACTRIS-2 project and the experimental campaigns that are dedicated to that objective.

Data availability. The data used in this work are publicly available in the Zenodo public data repository, https://doi.org/10.5281/zenodo.1115599 (Tsekeri, 2017).

Competing interests. The authors declare that they have no conflict of interest.

Special issue statement. This article is part of the special issue "EARLINET, the European Aerosol Research Lidar Network". It is not associated with a conference.

Acknowledgements. The research leading to these results has received funding from the European Union's Horizon 2020 Research and Innovation Programme ACTRIS-2 (grant agreement no. 654109). The work has been developed under the auspices of the ESA-ESTEC project "Characterization of Aerosol mixtures of Dust And Marine origin" contract no. IPL-PSO/FF/lf/14.489. The work was also supported by the European Research Council under the European Community's Horizon 2020 research and innovation framework programme/ERC grant agreement 725698 (D-TECT). The publication was supported by the European Union's Horizon 2020 Research and Innovation programme under grant agreement no. 602014, project ECARS (East European Centre for Atmospheric Remote Sensing). The authors acknowledge support through the Stavros Niarchos Foundation. BSC-DREAM8b simulations were performed on the Mare Nostrum supercomputer hosted by the Barcelona Supercomputing Center-Centro Nacional de Supercomputación (BSC).

Edited by: Richard Ferrare

Reviewed by: three anonymous referees

\section{References}

Althausen, D., Engelmann, R., Baars, H., Heese, B., Ansmann, A., Mueller, D., and Komppula, M.: Portable Raman lidar PollyXT for automated profiling of aerosol backscatter, extinction, and depolarization, J. Atmos. Ocean. Tech., 26, 2366-2378, https://doi.org/10.1175/2009JTECHA1304.1, 2009.

Ansmann, A., Tesche, M., Seifert, P., Groß, S., Freudenthaler, V., Apituley, A., Wilson, K. M., Serikov, I., Linné, H., Heinold, B., Hiebsch, A., Schnell, F., Schmidt, J., Mattis, I., Wandinger, U., and Wiegner, M.: Ash and fine-mode particle mass profiles from EARLINET-AERONET observations over central Europe after the eruptions of the Eyjafjallajökull volcano in 2010, J. Geophys. Res.-Atmos., 116, D00U02, https://doi.org/10.1029/2010JD015567, 2011

Ansmann, A., Seifert, P., Tesche, M., and Wandinger, U.: Profiling of fine and coarse particle mass: case studies of Saharan dust and Eyjafjallajökull/Grimsvötn volcanic plumes, Atmos. Chem. Phys., 12, 9399-9415, https://doi.org/10.5194/acp12-9399-2012, 2012.

Baars, H., Kanitz, T., Engelmann, R., Althausen, D., Heese, B., Komppula, M., Preißler, J., Tesche, M., Ansmann, A., Wandinger, U., Lim, J.-H., Ahn, J. Y., Stachlewska, I. S., Amiridis, V., Marinou, E., Seifert, P., Hofer, J., Skupin, A., Schneider, F., Bohlmann, S., Foth, A., Bley, S., Pfüller, A., Giannakaki, E., Lihavainen, H., Viisanen, Y., Hooda, R. K., Pereira, S. N., Bortoli, D., Wagner, F., Mattis, I., Janicka, L., Markowicz, K. M., Achtert, P., Artaxo, P., Pauliquevis, T., Souza, R. A. F., Sharma, V. P., van Zyl, P. G., Beukes, J. P., Sun, J., Rohwer, E. G., Deng, R., Mamouri, R.-E., and Zamorano, F.: An overview of the first decade of Polly NET: an emerging network of automated Raman-polarization lidars for continuous aerosol profiling, Atmos. Chem. Phys., 16, 5111-5137, https://doi.org/10.5194/acp16-5111-2016, 2016.

Babin, M., Morel, A., Fournier-Sicre, V., Fell, F., Stramski, D.: Light scattering properties of marine particles in coastal and open ocean waters as related to the particle mass concentration, Limnol. Oceanogr., 2, 843-859, https://doi.org/10.4319/lo.2003.48.2.0843, 2003.

Basart, S., Pérez, C., Nickovic, S., Cuevas, E., and Baldasano, J. M.: Development and evaluation of the BSCDREAM8b dust regional model over Northern Africa, the Mediterranean and the Middle East, Tellus B, 64, 18539, https://doi.org/10.3402/tellusb.v64i0.18539, 2012a.

Benavent-Oltra, J. A., Román, R., Granados-Muñoz, M. J., PérezRamírez, D., Ortiz-Amezcua, P., Denjean, C., Lopatin, A., Lyamani, H., Torres, B., Guerrero-Rascado, J. L., Fuertes, D., Dubovik, O., Chaikovsky, A., Olmo, F. J., Mallet, M., and Alados-Arboledas, L.: Comparative assessment of GRASP algorithm for a dust event over Granada (Spain) during ChArMExADRIMED 2013 campaign, Atmos. Meas. Tech., 10, 44394457, https://doi.org/10.5194/amt-10-4439-2017, 2017.

Binietoglou, I., Basart, S., Alados-Arboledas, L., Amiridis, V., Argyrouli, A., Baars, H., Baldasano, J. M., Balis, D., Belegante, L., Bravo-Aranda, J. A., Burlizzi, P., Carrasco, V., Chaikovsky, A., Comerón, A., D’Amico, G., Filioglou, M., Granados-Muñoz, M. J., Guerrero-Rascado, J. L., Ilic, L., Kokkalis, P., Maurizi, A., Mona, L., Monti, F., Muñoz-Porcar, C., Nicolae, D., Papayannis, A., Pappalardo, G., Pejanovic, G., Pereira, S. N., Perrone, M. R., Pietruczuk, A., Posyniak, M., Rocadenbosch, F., Rodríguez-Gómez, A., Sicard, M., Siomos, N., Szkop, A., Terradellas, E., Tsekeri, A., Vukovic, A., Wandinger, U., and Wagner, J.: A methodology for investigating dust model performance using synergistic EARLINET/AERONET 
dust concentration retrievals, Atmos. Meas. Tech., 8, 3577-3600, https://doi.org/10.5194/amt-8-3577-2015, 2015.

Bezantakos, S., Barmpounis, K., Giamarelou, M., Bossioli, E., Tombrou, M., Mihalopoulos, N., Eleftheriadis, K., Kalogiros, J., Allan, D. J., Bacak, A., Percival, C. J., Coe, H., and Biskos, G.: Chemical composition and hygroscopic properties of aerosol particles over the Aegean Sea, Atmos. Chem. Phys., 13, 1159511608, https://doi.org/10.5194/acp-13-11595-2013, 2013.

Bovchaliuk, V., Goloub, P., Podvin, T., Veselovskii, I., Tanre, D., Chaikovsky, A., Dubovik, O., Mortier, A., Lopatin, A., Korenskiy, M., and Victori, S.: Comparison of aerosol properties retrieved using GARRLiC, LIRIC, and Raman algorithms applied to multi-wavelength lidar and sun/sky-photometer data, Atmos. Meas. Tech., 9, 3391-3405, https://doi.org/10.5194/amt-9-33912016, 2016.

Brioude, J., Arnold, D., Stohl, A., Cassiani, M., Morton, D., Seibert, P., Angevine, W., Evan, S., Dingwell, A., Fast, J. D., Easter, R. C., Pisso, I., Burkhart, J., and Wotawa, G.: The Lagrangian particle dispersion model FLEXPART-WRF version 3.1, Geosci. Model Dev., 6, 1889-1904, https://doi.org/10.5194/gmd-6-18892013, 2013.

Chaikovsky, A., Dubovik, O., Holben, B., Bril, A., Goloub, P., Tanré, D., Pappalardo, G., Wandinger, U., Chaikovskaya, L., Denisov, S., Grudo, J., Lopatin, A., Karol, Y., Lapyonok, T., Amiridis, V., Ansmann, A., Apituley, A., Allados-Arboledas, L., Binietoglou, I., Boselli, A., D’Amico, G., Freudenthaler, V., Giles, D., Granados-Muñoz, M. J., Kokkalis, P., Nicolae, D., Oshchepkov, S., Papayannis, A., Perrone, M. R., Pietruczuk, A., Rocadenbosch, F., Sicard, M., Slutsker, I., Talianu, C., De Tomasi, F., Tsekeri, A., Wagner, J., and Wang, X.: Lidar-Radiometer Inversion Code (LIRIC) for the retrieval of vertical aerosol properties from combined lidar/radiometer data: development and distribution in EARLINET, Atmos. Meas. Tech., 9, 1181-1205, https://doi.org/10.5194/amt-9-1181-2016, 2016.

Cotton, W. R., Pielke, Sr., R. A., Walko, R. L., Liston, G. E., Tremback, C. J., Jiang, H., McAnelly, R. L., Harrington, J. Y., Nicholls, M. E., Carrio, G. G., and Mc Fadden, J. P.: RAMS 2001: Current status and future directions, Meteorol. Atmos. Phys., 82, 5-29, 2003.

di Sarra, A., Pace, G., Meloni, D., De Silvestri, L., Piacentino, S., and Monteleone, F.: Surface shortwave radiative forcing of different aerosol types in the central Mediterranean, Geophys. Res. Lett., 35, L02714, https://doi.org/10.1029/2007GL032395, 2008.

Dubovik, O.: Optimization of Numerical Inversion in Photopolarimetric Remote Sensing, in: Photopolarimetry in Remote Sensing, edited by: Videen, G., Yatskiv, Y., and Mishchenko, M., Kluwer Academic Publishers, Dordrecht, the Netherlands, 65106, 2004.

Dubovik, O. and King, M: A flexible inversion algorithm for retrieval of aerosol optical properties from Sun and sky radiance measurements, J. Geophys. Res., 105, 20673-20696, https://doi.org/10.1029/2000JD900282, 2000.

Dubovik, O., Smirnov, A., Holben, B. N., King, M. D., Kaufman, Y. J., Eck, T. F., and Slutsker, I.: Accuracy assessment of aerosol optical properties retrieval from AERONET sun and sky radiance measurements, J. Geophys. Res., 105, 9791-9806, 2000.

Dubovik, O., Holben, B., Eck, T., Smirnov, A., Kaufman, Y., King, M., Tanré, D., and Slutsker, I.: Variability of absorption and op- tical properties of key aerosol types observed in worldwide locations, J. Atmos. Sci., 59, 590-608, 2002.

Dubovik, O., Sinyuk, A., Lapyonok, T., Holben, B. N., Mishchenko, M., Yang, P., Eck, T. F., Volten, H., Muñoz, O., Veihelmann, B., van der Zande, W. J., Leon, J.-F., Sorokin, M., and Slutsker, I.: Application of spheroid models to account for aerosol particle nonsphericity in remote sensing of desert dust, J. Geophys. Res., 111, D11208, https://doi.org/10.1029/2005JD006619, 2006.

Dubovik, O., Lapyonok, T., Litvinov, P., Herman, M., Fuertes, D., Ducos, F., Lopatin, A., Chaikovsky, A., Torres, B., Derimian, Y., Huang, X., Aspetsberger, M., and Federspiel, C.: GRASP: a versatile algorithm for characterizing the atmosphere, SPIE: Newsroom, September, 2014.

Engelmann, R., Kanitz, T., Baars, H., Heese, B., Althausen, D., Skupin, A., Wandinger, U., Komppula, M., Stachlewska, I. S., Amiridis, V., Marinou, E., Mattis, I., Linné, H., and Ansmann, A.: The automated multiwavelength Raman polarization and water-vapor lidar Polly XT: the neXT generation, Atmos. Meas. Tech., 9, 1767-1784, https://doi.org/10.5194/amt-9-1767-2016, 2016.

Fernald, F. G., Herman, B. M., and Reagan, J. A.: Determination of aerosol height distributions by lidar, J. Appl. Meteorol., 11, 482-489, 1972.

Gerasopoulos E., Kouvarakis G., Babasakalis P., Vrekoussis M., Putaud, J. P., and Mihalopoulos N.: Origin and variability of particulate matter $\left(\mathrm{PM}_{10}\right)$ mass concentrations over the Eastern Mediterranean, Atmos. Environ., 40, 4679-4690, 2006.

Gong, S. L., Barrie, L. A., and Lazare, M.: Canadian Aerosol Module (CAM): a size-segregated simulation of atmospheric aerosol processes for climate and air quality models. 2. Global sea-salt aerosol and its budgets, J. Geophys. Res., 107, 4779, https://doi.org/10.1029/2001JD002004, 2002.

Granados-Muñoz, M. J., Guerrero-Rascado, J. L., Bravo-Aranda, J. A., Navas-Guzmán, F., Valenzuela, A., Lyamani, H., Chaikovsky, A., Wandinger, U., Ansmann, A., Dubovik, O., Grudo, J., and Alados-Arboledas, L.: Retrieving aerosol microphysical properties by Lidar-Radiometer Inversion Code (LIRIC) for different aerosol types, J. Geophys. Res., 119, 4836-4858, https://doi.org/10.1002/2013JD021116, 2014.

Granados-Muñoz, M. J., Bravo-Aranda, J. A., Baumgardner, D., Guerrero-Rascado, J. L., Pérez-Ramírez, D., Navas-Guzmán, F., Veselovskii, I., Lyamani, H., Valenzuela, A., Olmo, F. J., Titos, G., Andrey, J., Chaikovsky, A., Dubovik, O., Gil-Ojeda, M., and Alados-Arboledas, L.: A comparative study of aerosol microphysical properties retrieved from ground-based remote sensing and aircraft in situ measurements during a Saharan dust event, Atmos. Meas. Tech., 9, 1113-1133, https://doi.org/10.5194/amt9-1113-2016, 2016a.

Granados-Muñoz, M. J., Navas-Guzmán, F., Guerrero-Rascado, J. L., Bravo-Aranda, J. A., Binietoglou, I., Pereira, S. N., Basart, S., Baldasano, J. M., Belegante, L., Chaikovsky, A., Comerón, A., D’Amico, G., Dubovik, O., Ilic, L., Kokkalis, P., Muñoz-Porcar, C., Nickovic, S., Nicolae, D., Olmo, F. J., Papayannis, A., Pappalardo, G., Rodríguez, A., Schepanski, K., Sicard, M., Vukovic, A., Wandinger, U., Dulac, F., and AladosArboledas, L.: Profiling of aerosol microphysical properties at several EARLINET/AERONET sites during the July 2012 ChArMEx/EMEP campaign, Atmos. Chem. Phys., 16, 70437066, https://doi.org/10.5194/acp-16-7043-2016, 2016 b. 
Ho, S.-P., Peng, L., Anthes, R. A., Kuo, Y.-H., and Lin, H.-C.: Marine Boundary Layer Heights and Their Longitudinal, Diurnal, and Interseasonal Variability in the Southeastern Pacific Using COSMIC, CALIOP, and Radiosonde Data, J. Climate, 28, 28562872, 2015.

Holben, B. N., Eck, T. F., Slutsker, I., Tanre, D., Buis, J. P., Setzer, A., Vermote, E., Reagan, J. A., Kaufman, Y. J., Nakajima, T., Lavenu, F., Jankowiak, I., and Smirnov, A.: AERONET-A federated instrument network and data archive for aerosol characterization, Remote Sens. Environ., 66, 1-16, https://doi.org/10.1016/S0034-4257(98)00031-5, 1998.

Kandler, K., Benker, N., Cuevas, E., Ebert, M., Knippertz, P., Rodríguez, S., Schütz, L., Weinbruch, S.:Chemical composition and complex refractive index of Saharan Mineral Dust at Izaña, Tenerife (Spain) derived by electron microscopy, Atmos. Environ., 41, 8058-8074, https://doi.org/10.1016/j.atmosenv.2007.06.047, 2007

Kalivitis, N., Gerasopoulos, E., Vrekoussis, M., Kouvarakis, G., Kubilay, N., Hatzianastassiou, N., Vardavas, I., and Mihalopoulos, N.: Dust transport over the eastern Mediterranean derived from Total Ozone Mapping Spectrometer, Aerosol Robotic Network, and surface measurements, J. Geophys. Res., 112, D03202, https://doi.org/10.1029/2006JD007510, 2007.

Kazadzis, S., Bais, A., Balis, D., Kouremeti, N., Zempila, M., Arola, A., Giannakaki, E., Amiridis, V., and Kazantzidis, A.: Spatial and temporal UV irradiance and aerosol variability within the area of an OMI satellite pixel, Atmos. Chem. Phys., 9, 4593-4601, https://doi.org/10.5194/acp-9-4593-2009, 2009.

Klett, D.: Lidar inversion with variable backscatter/extinction ratios, Appl. Optics, 31, 1638-1643, 1985.

Kokkalis, P., Amiridis, V., Allan, J. D., Papayannis, A., Solomos, S., Binietoglou, I., Bougiatioti, A., Tsekeri, A., Nenes, A., Rosenberg, P. D., Marenco, F., Marinou, E., Vasilescu, J., Nicolae, D., Coe, H., Bacak, A., and Chaikovsky A.: Validation of LIRIC aerosol concentration retrievals using airborne measurements during a biomass burning episode over Athens, Atmos. Res., 183, 255-267, 2017.

Leeuw, G., Neele, F. P., Hill, M., Smith, M. H., and Vignali, E.: Production of sea spray aerosol in the surf zone, J. Geophys. Res.Atmos., 105, 29397-29409, 2000.

Lopatin, A., Dubovik, O., Chaikovsky, A., Goloub, P., Lapyonok, T., Tanré, D., and Litvinov, P.: Enhancement of aerosol characterization using synergy of lidar and sun-photometer coincident observations: the GARRLiC algorithm, Atmos. Meas. Tech., 6, 2065-2088, https://doi.org/10.5194/amt-6-2065-2013, 2013.

Marinou, E., Amiridis, V., Binietoglou, I., Tsikerdekis, A., Solomos, S., Proestakis, E., Konsta, D., Papagiannopoulos, N., Tsekeri, A., Vlastou, G., Zanis, P., Balis, D., Wandinger, U., and Ansmann, A.: Three-dimensional evolution of Saharan dust transport towards Europe based on a 9-year EARLINEToptimized CALIPSO dataset, Atmos. Chem. Phys., 17, 58935919, https://doi.org/10.5194/acp-17-5893-2017, 2017.

Mishra, A. K., Klingmueller, K., Fredj, E., Lelieveld, J., Rudich, Y., and Koren, I.: Radiative signature of absorbing aerosol over the eastern Mediterranean basin, Atmos. Chem. Phys., 14, 72137231, https://doi.org/10.5194/acp-14-7213-2014, 2014.

Monahan, E. C., Spiel, D. E., and Davidson, K. L.: A model of marine aerosol generation via whitecaps and wave disruption, in:
Oceanic Whitecaps, edited by: Monahan, E. C. and Mac Niocaill, G., Reidel, D., 167-174, 1986.

Müller, D., Böckmann, C., Kolgotin, A., Schneidenbach, L., Chemyakin, E., Rosemann, J., Znak, P., and Romanov, A.: Microphysical particle properties derived from inversion algorithms developed in the framework of EARLINET, Atmos. Meas. Tech., 9, 5007-5035, https://doi.org/10.5194/amt-9-5007-2016, 2016.

Nickovic, S., Kallos, G., Papadopoulos, A., and Kakaliagou, O.: A model for prediction of desert dust cycle in the atmosphere, J. Geophys. Res., 106, 18113-18130, https://doi.org/10.1029/2000JD900794, 2001.

Otto, S., de Reus, M., Trautmann, T., Thomas, A., Wendisch, M., and Borrmann, S.: Atmospheric radiative effects of an in situ measured Saharan dust plume and the role of large particles, Atmos. Chem. Phys., 7, 4887-4903, https://doi.org/10.5194/acp-74887-2007, 2007.

Papadimas, C. D., Hatzianastassiou, N., Matsoukas, C., Kanakidou, M., Mihalopoulos, N., and Vardavas, I.: The direct effect of aerosols on solar radiation over the broader Mediterranean basin, Atmos. Chem. Phys., 12, 7165-7185, https://doi.org/10.5194/acp-12-7165-2012, 2012.

Papayannis, A., Nicolae, D., Kokkalis, P., Binetoglou, I., Talianu, C., Belegante, L., Tsaknakis., G., Cazacu, M. M., Vetres, I., and Ilic, I.: Optical, size and mass properties of mixed type aerosols in Greece and Romania as observed by synergy of lidar and sunphotometers in combination with model simulations: A case study, Sci. Total Environ., 500-501, 277-294, 2014.

Pappalardo, G., Amodeo, A., Apituley, A., Comeron, A., Freudenthaler, V., Linné, H., Ansmann, A., Bösenberg, J., D’Amico, G., Mattis, I., Mona, L., Wandinger, U., Amiridis, V., AladosArboledas, L., Nicolae, D., and Wiegner, M.: EARLINET: towards an advanced sustainable European aerosol lidar network, Atmos. Meas. Tech., 7, 2389-2409, https://doi.org/10.5194/amt7-2389-2014, 2014.

Pérez, C., Nickovic, S., Pejanovic, G., Baldasano, J. M., and Ozsoy, E.: Interactive dust-radiation modeling: a step to improve weather forecasts, J. Geophys. Res., 11, D16206, https://doi.org/10.1029/2005JD006717, 2006.

Petters, M. D. and Kreidenweis, S. M.: A single parameter representation of hygroscopic growth and cloud condensation nucleus activity, Atmos. Chem. Phys., 7, 1961-1971, https://doi.org/10.5194/acp-7-1961-2007, 2007.

Pielke, R. A., Cotton, W. R., Walko, R. L., Tremback, C. J., Lyons, W. A., Grasso, L. D., Nicholls, M. E., Moran, M. D., Wesley, D. A., Lee, T. J., and Copeland, J. H.: A comprehensive meteorological modeling system - RAMS, Meteorol. Atmos. Phys., 49, 69-91, 1992.

Prospero, J. M.: Saharan dust transport over the North Atlantic Ocean and Mediterranean: an overview, in: The Impact of Desert Dust Across the Mediterranean, edited by: Guerzoni, S. and Chester, R., Kluwer Academic, Dordrecht, 133-151, 1996.

Raptis, P. I., Kokkalis, P., Amiridis, V., Taylor, M., and Kazadzis, S.: A case study of columnar marine and dust particle ratios calculated with photometric and lidar measurements during the CHARADMEXP campaign, Geophys. Res. Abstr., EGU20158942, EGU General Assembly 2015, Vienna, Austria, 2015.

Reid, J. S., Jonsson, H. H., Maring, H. B., Smirnov, A., Savoie, D. L., Cliff, S. S., Reid, E. A., Livingston, J. M., Meier, M. M., Dubovik, O., et al: Comparison of size and morphological mea- 
surements of coarse mode dust particles from Africa. J. Geophys. Res.-Atmos., 108, 8593, https://doi.org/10.1029/2002JD002485, 2003.

Sciare, J., Oikonomou, K., Favez, O., Liakakou, E., Markaki, Z., Cachier, H., and Mihalopoulos, N.: Long-term measurements of carbonaceous aerosols in the Eastern Mediterranean: evidence of long-range transport of biomass burning, Atmos. Chem. Phys., 8, 5551-5563, https://doi.org/10.5194/acp-8-5551-2008, 2008.

Seinfeld, J. H. and Pandis, S. N.: Atmospheric Chemistry and Physics: From Air Pollution to Climate Change, J. Wiley, Sons, Inc., New York, 1998.

Siomos, N., Balis, D. S., Poupkou, A., Liora, N., Dimopoulos, S., Melas, D., Giannakaki, E., Filioglou, M., Basart, S., and Chaikovsky, A.: Investigating the quality of modeled aerosol profiles based on combined lidar and sunphotometer data, Atmos. Chem. Phys., 17, 7003-7023, https://doi.org/10.5194/acp17-7003-2017, 2017.

Skamarock, W., Klemp, J. B., Dudhia, J., Gill, D. O., Barker, D., Duda, M. G., Huang, X.-Y., and Wang, W.: A description of the Advanced Research WRF version 3, NCAR Technical Note NCAR/TN-475+STR, https://doi.org/10.5065/D68S4MVH, 2008.

Snider, J. R. and Petters, M. D.: Optical particle counter measurement of marine aerosol hygroscopic growth, Atmos. Chem. Phys., 8, 1949-1962, https://doi.org/10.5194/acp-8-1949-2008, 2008.

Solomon, S., Qin, D., Manning, M., Chen, Z., Marquis, M., Averyt, K. B., Tignor M., and Miller, H. L.: Intergovernmental Panel on Climate Change, Climate Change 2007: The Physical Science Basis. Contribution of Working Group I to the Fourth Assessment Report of the Intergovernmental Panel on Climate Change, Cambridge Univ Press, Cambridge, UK, 2007.

Solomos, S., Kallos, G., Kushta, J., Astitha, M., Tremback, C., Nenes, A., and Levin, Z.: An integrated modeling study on the effects of mineral dust and sea salt particles on clouds and precipitation, Atmos. Chem. Phys., 11, 873-892, https://doi.org/10.5194/acp-11-873-2011, 2011.

Stock, M., Cheng, Y. F., Birmili, W., Massling, A., Wehner, B., Müller, T., Leinert, S., Kalivitis, N., Mihalopoulos, N., and Wiedensohler, A.: Hygroscopic properties of atmospheric aerosol particles over the Eastern Mediterranean: implications for regional direct radiative forcing under clean and polluted conditions, Atmos. Chem. Phys., 11, 4251-4271, https://doi.org/10.5194/acp-11-4251-2011, 2011.

Tsekeri, A.: Data for publication on GARRLiC and LIRIC [Data set], Zenodo, available at: https://doi.org/10.5281/zenodo.1115599, last access: 15 December 2017.
Tsekeri, A., Amiridis, V., Kokkalis, P., Basart, S., Chaikovsky, A., Dubovik, O., Mamouri, R. E., Papayannis, A., and Baldasano, J. M.: Application of a Synergetic Lidar and Sunphotometer Algorithm for the Characterization of a Dust Event Over Athens, Greece, British Journal of Environment and Climate Change, 3 , 531-546, https://doi.org/10.9734/BJECC/2013/2615, 2013.

Tsekeri, A., Amiridis, V., Marenco, F., Nenes, A., Marinou, E., Solomos, S., Rosenberg, P., Trembath, J., Nott, G. J., Allan, J., Le Breton, M., Bacak, A., Coe, H., Percival, C., and Mihalopoulos, N.: Profiling aerosol optical, microphysical and hygroscopic properties in ambient conditions by combining in situ and remote sensing, Atmos. Meas. Tech., 10, 83-107, https://doi.org/10.5194/amt-10-83-2017, 2017.

Veselovskii, I., Goloub, P., Podvin, T., Bovchaliuk, V., Derimian, Y., Augustin, P., Fourmentin, M., Tanre, D., Korenskiy, M., Whiteman, D. N., Diallo, A., Ndiaye, T., Kolgotin, A., and Dubovik, O.: Retrieval of optical and physical properties of African dust from multiwavelength Raman lidar measurements during the SHADOW campaign in Senegal, Atmos. Chem. Phys., 16, 70137028, https://doi.org/10.5194/acp-16-7013-2016, 2016.

Vrekoussis, M., Liakakou, E., Koçak, M., Kubilay, N., Oikonomou, K., Sciare, J., and Mihalopoulos, N.: Seasonal variability of optical properties of aerosols in the Eastern Mediterranean, Atmos. Environ., 39, 7083-7094, 2005.

Wagner, J., Ansmann, A., Wandinger, U., Seifert, P., Schwarz, A., Tesche, M., Chaikovsky, A., and Dubovik, O.: Evaluation of the Lidar/Radiometer Inversion Code (LIRIC) to determine microphysical properties of volcanic and desert dust, Atmos. Meas. Tech., 6, 1707-1724, https://doi.org/10.5194/amt-6-1707-2013, 2013.

Wagner, R., Ajtai, T., Kandler, K., Lieke, K., Linke, C., Müller, T., Schnaiter, M., and Vragel, M.: Complex refractive indices of Saharan dust samples at visible and near UV wavelengths: a laboratory study, Atmos. Chem. Phys., 12, 2491-2512, https://doi.org/10.5194/acp-12-2491-2012, 2012.

Wandinger, U. and Ansmann, A.: Experimental determination of the lidar overlap profile with Raman lidar, Appl. Optics, 41, 511514, 2002.

Zhang, K. M., Knipping, E. M., Wexler, A. S., Bhave, P. V., and Tonnesen, G. S.: Size distribution of sea-salt emissions as a function of relative humidity, Atmos. Environ., 39, 3373-3379, 2005. 